\title{
Identification and characterisation of tertiary lymphoid organs in human type 1 diabetes
}

\author{
Éva Korpos $^{1,2}$ (I) Nadir Kadri ${ }^{3}$ (D) - Sophie Loismann ${ }^{1,2} \cdot$ Clais R. Findeisen $^{1,2}$ (D) Frank Arfuso $^{1,2}$ (I) \\ George W. Burke III ${ }^{5}$ (D) Sarah J. Richardson ${ }^{6}$ (D) Noel G. Morgan $^{6}$ (D) Marika Bogdani $^{7}$ (D) A Alberto Pugliese ${ }^{8,9,10}$ (D) \\ Lydia Sorokin $^{1,2}$ (D)
}

Received: 12 August 2020 / Accepted: 28 January 2021 / Published online: 29 April 2021

(C) The Author(s) 2021

\begin{abstract}
Aims/hypothesis We and others previously reported the presence of tertiary lymphoid organs (TLOs) in the pancreas of NOD mice, where they play a role in the development of type 1 diabetes. Our aims here are to investigate whether TLOs are present in the pancreas of individuals with type 1 diabetes and to characterise their distinctive features, in comparison with TLOs present in NOD mouse pancreases, in order to interpret their functional significance.

Methods Using immunofluorescence confocal microscopy, we examined the extracellular matrix (ECM) and cellular constituents of pancreatic TLOs from individuals with ongoing islet autoimmunity in three distinct clinical settings of type 1 diabetes: at risk of diabetes; at/after diagnosis; and in the transplanted pancreas with recurrent diabetes. Comparisons were made with TLOs from 14-week-old NOD mice, which contain islets exhibiting mild to heavy leucocyte infiltration. We determined the frequency of the TLOs in human type 1diabetes with insulitis and investigated the presence of TLOs in relation to age of onset, disease duration and disease severity.

Results TLOs were identified in preclinical and clinical settings of human type 1 diabetes. The main characteristics of these TLOs, including the cellular and ECM composition of reticular fibres (RFs), the presence of high endothelial venules and immune cell subtypes detected, were similar to those observed for TLOs from NOD mouse pancreases. Among 21 donors with clinical type 1 diabetes who exhibited insulitis, 12 had TLOs and had developed disease at younger age compared with those lacking TLOs. Compartmentalised TLOs with distinct T cell and B cell zones were detected in donors with short disease duration. Overall, TLOs were mainly associated with insulincontaining islets and their frequency decreased with increasing severity of beta cell loss. Parallel studies in NOD mice further revealed some differences in so far as regulatory $\mathrm{T}$ cells were essentially absent from human pancreatic TLOs and CCL21 was not associated with RFs.
\end{abstract}

Éva Korpos

korpos@uni-muenster.de

1 Institute of Physiological Chemistry and Pathobiochemistry, University of Muenster, Muenster, Germany

2 Cells-in-Motion Interfaculty Centre, University of Muenster, Muenster, Germany

3 Science for Life Laboratory, Department of Medicine, Karolinska Institute, Karolinska University Hospital, Solna, Stockholm, Sweden

4 Present address: School of Human Sciences, The University of Western Australia, Perth, WA, Australia

5 Department of Surgery, Division of Transplantation, Leonard M. Miller School of Medicine, University of Miami, Miami, FL, USA
6 Institute of Biomedical \& Clinical Science, University of Exeter, Exeter, UK

7 Matrix Biology Program, Benaroya Research Institute, Seattle, WA, USA

8 Diabetes Research Institute, Leonard M. Miller School of Medicine, University of Miami, Miami, FL, USA

9 Division of Endocrinology and Metabolism, Department of Medicine, Leonard M. Miller School of Medicine, University of Miami, Miami, FL, USA

10 Department of Microbiology and Immunology, Leonard M. Miller School of Medicine, University of Miami, Miami, FL, USA 


\section{Research in context}

\section{What is already known about this subject?}

- Tertiary lymphoid organs (TLOs) occur in the pancreas of NOD mice at sites of extensive immune cell infiltration

- Partial molecular characterisation of TLOs in murine NOD pancreases has been reported

- Pancreatic TLOs in human type 1 diabetes have been described in a single individual, 18 years after diagnosis

What is the key question?

- Do TLOs also occur in human type 1 diabetes and are they molecularly and functionally similar to NOD mouse TLOs?

What are the new findings?

- TLOs were identified and characterised in human pancreases with islet autoimmunity in three different clinical settings

- The TLOs of human and mouse type 1 diabetes are structurally and molecularly similar, exhibiting high endothelial venule formation, a biochemically similar reticular fibre network, fibroblastic reticular cells and T cells and B cells

- TLOs were mostly associated with insulin-positive islets with immune cell aggregates, suggesting a role in early stages of disease

How might this impact on clinical practice in the foreseeable future?

- Improved understanding of the cellular interactions associated with islet autoimmunity can lead to new therapies

Conclusions/interpretation We demonstrate a novel feature of pancreas pathology in type 1 diabetes. TLOs represent a potential site of autoreactive effector $\mathrm{T}$ cell generation in islet autoimmunity and our data from mouse and human tissues suggest that they disappear once the destructive process has run its course. Thus, TLOs may be important for type 1 diabetes progression.

Keywords Autoimmunity $\cdot$ Basement membrane $\cdot$ Fibroblastic reticular cells $\cdot$ High endothelial venules $\cdot$ Lymph node $\cdot$ Reticular fibres $\cdot$ Tertiary lymphoid organs $\cdot$ Transplantation $\cdot$ Type 1 diabetes

$\begin{array}{ll}\text { Abbreviations } \\ \text { aAb } & \text { Autoantibody } \\ \text { BM } & \text { Basement membrane } \\ \text { EADB } & \text { Exeter Archival Diabetes Biobank } \\ \text { ECM } & \text { Extracellular matrix } \\ \text { FDC } & \text { Follicular dendritic cell } \\ \text { FRC } & \text { Fibroblastic reticular cell } \\ \text { FOXP3 } & \text { Forkhead box P3 } \\ \text { GADA } & \text { GAD aAb } \\ \text { HEV } & \text { High endothelial venule } \\ \text { IAA } & \text { Insulin aAb } \\ \text { IA-2A } & \text { Tyrosine phosphatase-related islet antigen } 2 \text { aAb } \\ \text { LN } & \text { Lymph node } \\ \text { nPOD } & \text { Network for Pancreatic Organ } \\ & \text { Donors with Diabetes } \\ \text { PDGFr } \beta & \text { Platelet-derived growth factor receptor } \beta \\ \text { PLM } & \text { Pan-laminin } \\ \text { RF } & \text { Reticular fibre } \\ \text { SPK } & \text { Simultaneous pancreas and kidney } \\ \text { TLO } & \text { Tertiary lymphoid organ } \\ \text { ZnT8A } & \text { Zinc transporter } 8 \text { aAb } \\ & \end{array}$

\section{Introduction}

Tertiary lymphoid organs (TLOs), highly organised structures compartmentalised into $\mathrm{T}$ cell and $\mathrm{B}$ cell zones by a reticular fibre (RF) network, form in inflamed tissues during chronic infection, autoimmunity and cancer [1]. The impact of TLOs on disease varies. During acute infection TLOs support the immune response and clearance of pathogens $[2,3]$ and in cancer TLOs support or suppress the immune response against tumour cells, depending on tumour type [4]. TLOs worsen the severity of most autoimmune diseases $[5,6]$.

TLOs show structural and functional similarities to secondary lymphoid organs, even though they form after birth. TLOs generate local immune responses in chronically inflamed tissues and are not surrounded by a fibrous capsule [7]. Like lymph nodes (LNs), TLOs are characterised by an extensive RF network, consisting of a unique inner core of fibrillar collagens surrounded by basement membrane (BM) proteins and enclosed in a sheath of fibroblastic reticular cells (FRCs) $[8,9]$. TLOs contain high endothelial venules (HEVs), specialised postcapillary venules $[10]$ through which CCR $7^{+}$ 
$\mathrm{T}$ cells and naive $\mathrm{B}$ cells $\left(\mathrm{CCR} 7^{\mathrm{low}}\right)$ are recruited from the circulation to the site of inflammation [11]. Like LNs, mature TLOs display clear compartmentalisation of $\mathrm{T}$ cells and $\mathrm{B}$ cells, with higher RF density in $\mathrm{T}$ cell zones compared with $\mathrm{B}$ cell zones. T cells are supported by FRCs and the B cells by follicular dendritic cells (FDCs) [12]. These features of RFs, FRCs and FDCs allow distinction between immature and mature TLOs even in the absence of staining for B cells and $\mathrm{T}$ cells. RFs act as conduits for the transport of small molecules and soluble antigens $(<70 \mathrm{kDa})$ from peripheral sites of inflammation to HEVs, required for the rapid recruitment of lymphocytes [8, 13, 14]. Hence, RFs promote inflammation.

TLOs were described in the pancreas of NOD mice, a model of autoimmune type 1 diabetes [15-17]. There are no published studies reporting direct evidence of TLOs in the pancreas of humans with type 1 diabetes, except for a recent case report of a person aged 66 years who had developed type 1 diabetes 18 years earlier, at age 48 [18]. We investigated the existence of TLOs in human pancreases with islet autoimmunity in three different clinical settings: preclinical, defined by the expression of at least two disease-associated autoantibodies (aAbs); clinically diagnosed type 1 diabetes [19]; and recurrent diabetes in transplanted pancreas [20,21]. Using a unique repertoire of cellular and extracellular matrix (ECM) markers, we compared TLOs in human and NOD mouse pancreas.

\section{Methods}

Human samples We studied pancreas sections from organ donors without diabetes and from donors with ongoing islet autoimmunity in three distinct clinical settings of type 1 diabetes: preclinical; clinically diagnosed; and recurrent disease in the transplanted pancreas. Key clinical and laboratory characteristics of the individuals examined are listed in Table 1.

Specifically, the Network for Pancreatic Organ Donors with Diabetes (nPOD; www.JDRFnPOD.org) provided pancreas cryosections from the following groups:

- five organ donors without diabetes and negative for type 1 diabetes-associated autoantibodies ( $\mathrm{aAb}^{-}$control group);

- thirteen organ donors positive for one $(n=7)$ or more $(n=$ 6) type 1 diabetes-associated autoantibodies, of which 1/7 and $3 / 6$, respectively, had insulitis;

- twenty organ donors with type 1 diabetes (additionally, paraffin sections from four autopsies were provided by the Exeter Archival Diabetes Biobank [EADB; https:// foulis.vub.ac.be/]). Among these 24 donors, $21 \mathrm{had}$ insulitis and nine had disease duration shorter than 6 months. The disease duration among those with insulitis was $0-7$ years. This group included three donors with long disease duration (32.5-83 years) who lacked insulitis and insulin staining in the islets;

- three individuals with long-standing type 1 diabetes who experienced recurrence of disease in the transplanted pancreas several years after successful simultaneous pancreas and kidney (SPK) transplantation, despite chronic immunosuppression (Table 2). All pancreas transplant biopsies were from individuals who displayed insulitis and residual islets with insulin-positive beta cells and these individuals had the cardinal features of recurrent type 1 diabetes we previously described [20].

All tissue donors were de-identified and samples were obtained with the necessary ethical approvals.

Immunofluorescence microscopy Immunofluorescence staining of pancreas cryosections was performed as described [22]. Sections were fixed in methanol at $-20^{\circ} \mathrm{C}$, washed, blocked with $1 \%$ BSA in PBS and incubated overnight at $4{ }^{\circ} \mathrm{C}$ with primary antibody diluted in blocking solution. After washing, sections were incubated overnight at $4^{\circ} \mathrm{C}$ with secondary antibodies. Paraffin sections were rehydrated and submitted to antigen retrieval by heating the sections for $30 \mathrm{~min}$ in $10 \mathrm{mmol} / 1$ citrate buffer, $\mathrm{pH} 6.0$ in a microwave $(700 \mathrm{~W})$. Sections were treated with Pronase (Roche, Germany) $(1 \mathrm{mg} / \mathrm{ml}$ Pronase in $50 \mathrm{mmol} / \mathrm{l}$ Tris- $\mathrm{HCl}[\mathrm{pH} 7.5]$ and $5 \mathrm{mmol} / \mathrm{l}$ EDTA) for $15 \mathrm{~min}$ at $37^{\circ} \mathrm{C}$ to retrieve masked ECM molecules. Blocking and incubation with the primary and secondary antibodies were performed as for cryosections. The primary antibodies employed are listed in electronic supplementary material (ESM) Table 1. Human thymus and LN sections were used to validate the primary antibodies. The specificity of secondary antibodies was verified by omitting the primary antibodies from the staining procedure (ESM Fig. 1). The sections were examined using a Zeiss AxioImager (Zeiss, Germany) or an LSM700 microscope (Zeiss).

Quantification of TLOs in type 1 diabetes human samples Pancreas cryosections stained for pan-laminin (PLM), CD45 and insulin were used to count insulin-positive and insulinnegative islets (ESM Fig. 2) and associated aggregated or intermixed $\mathrm{CD} 45^{+}$cell infiltrates. Paraffin sections were stained for collagen type VI instead of PLM since the antigen retrieval for PLM was not compatible with cell surface staining. Serial sections were stained for MECA79 to visualise HEVs [10]. CD3 and CD20 staining was used to identify T cells and B cells. The density of RFs identified by PLM and the presence of FDCs helped to differentiate immature TLOs from mature TLOs in the absence of specific staining for $T$ cells and B cells in donor no. 6362. Insulitis was defined according to the consensus definition given by CampbellThompson et al [23] as at least $15 \mathrm{CD} 45^{+}$cells adjacent or 
Table 1 Clinical characteristics of the organ donors

\begin{tabular}{|c|c|c|c|c|c|c|c|c|c|c|c|}
\hline \multirow[t]{2}{*}{ Donor characteristic } & \multirow[t]{2}{*}{ Donor no. } & \multirow[t]{2}{*}{ Age (years) } & \multirow[t]{2}{*}{ Sex } & \multirow{2}{*}{$\begin{array}{l}\text { Age at type } 1 \\
\text { diabetes } \\
\text { diagnosis (years) }\end{array}$} & \multirow{2}{*}{$\begin{array}{l}\text { Diabetes } \\
\text { duration } \\
\text { (years) }\end{array}$} & \multicolumn{4}{|c|}{ Antibody status } & \multirow[t]{2}{*}{ Insulitis } & \multirow{2}{*}{$\begin{array}{l}\text { C- } \\
\text { peptide } \\
(\mathrm{nmol} / \mathrm{l})\end{array}$} \\
\hline & & & & & & GADA & $\begin{array}{l}\text { IA- } \\
2 \mathrm{~A}\end{array}$ & ZnT8A & mIAA & & \\
\hline \multirow{5}{*}{$\begin{array}{l}\text { Non-diabetic aAb } \\
\quad(n=5)\end{array}$} & nPOD 6098 & 17.8 & M & $\mathrm{n} / \mathrm{a}$ & $\mathrm{n} / \mathrm{a}$ & - & - & - & - & - & 0.46 \\
\hline & nPOD 6230 & 16 & M & $\mathrm{n} / \mathrm{a}$ & $\mathrm{n} / \mathrm{a}$ & - & - & - & - & - & 1.72 \\
\hline & nPOD 6339 & 23.3 & M & $\mathrm{n} / \mathrm{a}$ & $\mathrm{n} / \mathrm{a}$ & - & - & - & - & - & 3.49 \\
\hline & nPOD 6335 & 18.8 & M & $\mathrm{n} / \mathrm{a}$ & $\mathrm{n} / \mathrm{a}$ & - & - & - & - & - & 2.93 \\
\hline & nPOD 6430 & 27.1 & M & $\mathrm{n} / \mathrm{a}$ & $\mathrm{n} / \mathrm{a}$ & - & - & - & - & - & 3.68 \\
\hline \multirow{7}{*}{$\begin{array}{l}\text { Non-diabetic single } \\
\mathrm{aAb}^{+}(n=7)\end{array}$} & nPOD 6027 & 18.8 & M & $\mathrm{n} / \mathrm{a}$ & $\mathrm{n} / \mathrm{a}$ & - & - & + & - & - & $\mathrm{n} / \mathrm{a}$ \\
\hline & nPOD6123 & 23.2 & $\mathrm{~F}$ & $\mathrm{n} / \mathrm{a}$ & $\mathrm{n} / \mathrm{a}$ & + & - & - & - & - & 0.66 \\
\hline & nPOD6151 & 30 & M & $\mathrm{n} / \mathrm{a}$ & $\mathrm{n} / \mathrm{a}$ & + & - & - & - & - & 1.81 \\
\hline & nPOD6181 & 31.9 & M & $\mathrm{n} / \mathrm{a}$ & $\mathrm{n} / \mathrm{a}$ & + & - & - & - & - & 0.19 \\
\hline & nPOD6301 & 26 & M & $\mathrm{n} / \mathrm{a}$ & $\mathrm{n} / \mathrm{a}$ & + & - & - & - & - & 1.29 \\
\hline & nPOD 6310 & 28 & $\mathrm{~F}$ & $\mathrm{n} / \mathrm{a}$ & $\mathrm{n} / \mathrm{a}$ & + & - & - & - & + & 3.48 \\
\hline & nPOD 6314 & 21 & M & $\mathrm{n} / \mathrm{a}$ & $\mathrm{n} / \mathrm{a}$ & + & - & - & - & - & 0.49 \\
\hline \multirow{6}{*}{$\begin{array}{l}\text { Non-diabetic multiple } \\
\qquad \mathrm{aAb}^{+}(n=6)\end{array}$} & nPOD 6080 & 69.2 & $\mathrm{~F}$ & $\mathrm{n} / \mathrm{a}$ & $\mathrm{n} / \mathrm{a}$ & + & - & - & + & - & 0.60 \\
\hline & nPOD 6158 & 40.3 & M & $\mathrm{n} / \mathrm{a}$ & $\mathrm{n} / \mathrm{a}$ & + & - & - & + & - & 1.85 \\
\hline & nPOD 6167 & 37 & M & $\mathrm{n} / \mathrm{a}$ & $\mathrm{n} / \mathrm{a}$ & - & + & + & - & - & 1.79 \\
\hline & nPOD 6197 & 22 & M & $\mathrm{n} / \mathrm{a}$ & $\mathrm{n} / \mathrm{a}$ & + & + & - & - & + & 5.78 \\
\hline & nPOD 6267 & 23 & $\mathrm{~F}$ & $\mathrm{n} / \mathrm{a}$ & $\mathrm{n} / \mathrm{a}$ & + & + & - & - & + & 5.49 \\
\hline & nPOD 6450 & 22 & $\mathrm{~F}$ & $\mathrm{n} / \mathrm{a}$ & $\mathrm{n} / \mathrm{a}$ & + & - & + & - & + & 1.80 \\
\hline \multirow{24}{*}{$\begin{array}{l}\text { Donors with type } 1 \\
\text { diabetes }(n=24)\end{array}$} & nPOD 6362 & 24.9 & M & 24.9 & 0 & + & - & - & - & + & 0.12 \\
\hline & nPOD 6228 & 18 & M & 18 & 0 & + & + & + & - & + & 0.03 \\
\hline & EADB E405 & 8 & $\mathrm{~F}$ & 7.98 & $<0.019$ & $\mathrm{n} / \mathrm{a}$ & $\mathrm{n} / \mathrm{a}$ & $\mathrm{n} / \mathrm{a}$ & $\mathrm{n} / \mathrm{a}$ & + & $\mathrm{n} / \mathrm{a}$ \\
\hline & EADB SC115 & 1.25 & $\mathrm{~F}$ & 1.24 & 0.008 & $\mathrm{n} / \mathrm{a}$ & $\mathrm{n} / \mathrm{a}$ & $\mathrm{n} / \mathrm{a}$ & $\mathrm{n} / \mathrm{a}$ & + & $\mathrm{n} / \mathrm{a}$ \\
\hline & EADB E124B & 17 & M & 16.98 & 0.02 & $\mathrm{n} / \mathrm{a}$ & $\mathrm{n} / \mathrm{a}$ & $\mathrm{n} / \mathrm{a}$ & $\mathrm{n} / \mathrm{a}$ & + & $\mathrm{n} / \mathrm{a}$ \\
\hline & EADB E308 & 3 & $\mathrm{~F}$ & 2.92 & 0.08 & $\mathrm{n} / \mathrm{a}$ & $\mathrm{n} / \mathrm{a}$ & $\mathrm{n} / \mathrm{a}$ & $\mathrm{n} / \mathrm{a}$ & + & $\mathrm{n} / \mathrm{a}$ \\
\hline & nPOD6209 & 5 & $\mathrm{~F}$ & 4.75 & 0.25 & - & + & + & + & + & 0.03 \\
\hline & nPOD 6414 & 23.1 & M & 22.67 & 0.43 & + & - & + & $t^{\mathrm{a}}$ & + & 0.05 \\
\hline & nPOD 6247 & 24 & M & 23.4 & 0.6 & - & - & - & $t^{\mathrm{a}}$ & + & 0.15 \\
\hline & nPOD 6052 & 12 & M & 11 & 1 & + & - & - & - & + & 0.05 \\
\hline & nPOD 6224 & 21 & $\mathrm{~F}$ & 19.5 & 1.5 & - & - & - & - & + & $<0.01$ \\
\hline & nPOD 6342 & 14 & $\mathrm{~F}$ & 12 & 2 & + & - & - & $+^{\mathrm{a}}$ & + & 0.08 \\
\hline & nPOD 6371 & 12.5 & $\mathrm{~F}$ & 10.5 & 2 & + & + & + & $+^{\mathrm{a}}$ & + & 0.03 \\
\hline & nPOD 6396 & 17.1 & $\mathrm{~F}$ & 15.1 & 2 & - & - & - & - & + & 0.01 \\
\hline & nPOD 6195 & 19.3 & M & 14.3 & 5 & + & + & + & $+^{\mathrm{a}}$ & + & 0.01 \\
\hline & nPOD 6212 & 20 & M & 15 & 5 & + & - & - & - & + & 0.01 \\
\hline & nPOD 6243 & 13 & M & 8 & 5 & - & - & - & $+^{\mathrm{a}}$ & + & 0.13 \\
\hline & nPOD 6306 & 19 & M & 14 & 5 & - & - & - & $+^{\mathrm{a}}$ & + & 0.01 \\
\hline & nPOD 6325 & 20 & $\mathrm{~F}$ & 14 & 6 & + & + & - & $+^{\mathrm{a}}$ & + & 0.04 \\
\hline & nPOD 6070 & 22.6 & $\mathrm{~F}$ & 15.6 & 7 & + & - & - & $+^{\mathrm{a}}$ & + & 0.01 \\
\hline & nPOD 6245 & 22 & M & 15 & 7 & + & + & - & - & + & 0.01 \\
\hline & nPOD 6302 & 38.5 & M & 6 & 32.5 & - & - & - & - & - & 0.05 \\
\hline & nPOD 6085 & 71 & $\mathrm{~F}$ & 8 & 63 & - & - & - & $+^{*^{\mathrm{a}}}$ & - & 0.01 \\
\hline & nPOD 6086 & 89 & $\mathrm{~F}$ & 5 & 84 & - & - & - & - & - & 0.01 \\
\hline
\end{tabular}

${ }^{a}$ If the individuals have been on exogenous insulin for more than 10 days the mIAA is not a reliable marker for autoimmunity

$\mathrm{F}$, female sex; M, male sex; mIAA, micro IAA 
Table 2 Clinical characteristics of donors where recurrent type 1 diabetes developed after SPK transplantation

\begin{tabular}{llll}
\hline Characteristic & \multicolumn{2}{l}{ Donor no. } & \\
\cline { 2 - 4 } & nPOD 3626 & nPOD 3678 & nPOD 3681 \\
\hline Sex & M & M & M \\
Age at type 1 diabetes onset, years & 29 & 14 & 12 \\
Age at transplant, years & 43 & 39 & 35 \\
Ab status at transplant & & & - \\
GADA & - & + & - \\
IA-2A & + & - & - \\
ZnT8A & - & - & 40 \\
Age at biopsy, years & 63 & 49 & - \\
Ab status at biopsy & & & + \\
GADA & + & + & + \\
IA-2A & + & + & $93.4(10.7)$ \\
ZnT8A & - & + & 40 \\
HbA ${ }_{1 \mathrm{c}}$ at biopsy, mmol/mol (\%) & $115.3(12.7)$ & $94.5(10.6)$ & 4.9 \\
Age at biopsy, years & 63 & 49 & 0.6 \\
Time from transplant to diabetes recurrence, years & 17.2 & 8 & 1.4 \\
Duration of diabetes recurrence at biopsy, years & 1.4 & & \\
\hline
\end{tabular}

Ab, antibody; M, male sex within three islets per section. Control, non-diabetic donor samples were not included in quantification since insulitis was not detected in any of them. To assess TLOs in relation to disease severity, we classified pancreatic islets into four categories representing different phases of the disease process: phase 0 (normal, insulin positive, no insulitis); phase 1 (insulin positive, with insulitis); phase 2 (insulin negative with insulitis); and phase 3 (insulin negative, no insulitis, also known as pseudo-atrophic islets).

Electron microscopy Samples for electron microscopy were prepared according to standard protocols [24] and analysed with an electron microscope (EM-410; Philips, the Netherlands).

Animals NOD mice (Bomholtgaard, Ry, Denmark) were screened for diabetes by urine analyses of glucosuria (Combur3 Test; Roche). The mice were housed in the animal facility of the Institute of Physiological Chemistry and Pathobiochemistry, University of Muenster, on a $12 \mathrm{~h}$ lightdark cycle, and were fed with regular diet and given water ad libitum. Animal experiments followed Swedish and German animal welfare guidelines. Fourteen-week-old female NOD mice $(n=6)$ were used, since at this age all severity stages of inflamed islets are found in the pancreas. Mice were killed by cervical dislocation. Organs were frozen and cut by cryotome.

Statistical analysis The significance of the difference between two or more groups of data was evaluated using the Mann-
Whitney $U$ test and the Kruskal-Wallis test, respectively. Correlation analysis was performed using the non-parametric Spearman's rank correlation test. Contingency analysis was performed using $\chi^{2}$ (and Fisher's exact) test. $p<0.05$ was considered statistically significant. All analyses were performed using GraphPad Prism version 9.00 for Windows (GraphPad Software, San Diego, CA, USA).

As far as possible, the NIH guidelines for reporting of experimental conditions were employed. However, randomisation and blinded assessment of samples were not possible because of the limited numbers of human samples of defined conditions available and the need for their fast use upon arrival from nPOD.

\section{Results}

We examined pancreas specimens from donors with islet autoimmunity and/or type 1 diabetes (Tables 1 and 2) provided by the nPOD [25] and EADB repositories [26]. We used immunofluorescence staining and confocal microscopy to assess markers of TLO formation, including RFs, HEVs, chemokines and immune cell aggregates (ESM Table 1). Comparisons were made to pancreatic TLOs from NOD mice, and studies included in-depth characterisation of RFs in NOD mice.

TLOs in the human pancreas with islet autoimmunity in donors with type 1 diabetes Of the 24 donors with clinically 
diagnosed type 1 diabetes, 21 had insulitis and a diabetes duration of $0-7$ years (Table 1). Twelve of these 21 donors had pancreatic TLOs as revealed by staining for T cells and B cells, RFs and MECA79 (Fig. 1a, b, d, e). T cells and B cells appeared to be intermixed in immature TLOs (Fig. 1b) and organised into T cell and B cell compartments in mature TLOs (Fig. 1e). The peri-islet BM appeared to be intact in periinsulitis lesions where immune cells accumulated at one pole of the islet (Fig. 1b) and was breached at sites where immune cells penetrated the islet (Fig. 1c). TLOs were associated with insulin-positive islets in 7/12 donors, with both insulinpositive and insulin-negative islets in 4/12 donors; in a single donor, TLOs were rarely associated with insulin-negative islets (Table 3 ). The mean age of diagnosis was significantly lower among donors with TLOs compared with those without TLOs (mean \pm SD: $11.35 \pm 6.59$ vs $16.74 \pm 4.76$ years, $p<0.05$, Fig. 1f); however, there was no significant difference in disease duration (Fig. 1g). The frequency of TLOs was significantly different according to disease severity, with the highest frequency found in islets with insulitis (phase 1 and 2 islets) (Fig. 1h, $p<0.001$, Kruskal-Wallis test). When analysing the islets with insulitis among the 12 donors with TLOs and type 1 diabetes, there was an inverse correlation between the frequency of islets with TLOs and age of onset and disease duration (ESM Fig. 3), although this did not reach statistical significance; in this analysis, we calculated frequencies for phase 1 and 2 islets, phases when TLOs were observed. Of note, 39/383 (10.18\%) insulin-positive islets with insulitis had TLOs compared with 10/204 (4.9\%) insulin-negative islets with insulitis $\left(p=0.0276, \chi^{2}\right.$ [and Fisher's exact] test).

Most of the TLOs showed mixed T cell and B cell aggregates (8/12 donors) (Fig. 1b). TLOs with compartmentalised $\mathrm{T}$ cell and B cell areas were detected in only four donors with type 1 diabetes (Fig. 1d, e, Table 3 and ESM Fig. 4); however, in these samples TLOs with intermixed B cells and T cells predominated and compartmentalised TLOs represented 20$33 \%$ of the total TLOs. The frequency of TLOs was not statistically different in donors with compartmentalised TLOs compared with those with intermixed TLOs (Fig. 1i). We observed no significant differences in the mean age at diabetes diagnosis of donors with compartmentalised vs intermixed TLOs or those lacking TLOs (Fig. 1j). Disease duration was significantly shorter in donors with compartmentalised TLOs vs donors with intermixed TLOs and vs donors with no TLOs, respectively (mean \pm SD duration: $0.03 \pm 0.035,2.909 \pm$ 2.709 years and $2.948 \pm 2.564$, respectively; $p<0.05$, Fig. $1 \mathrm{k})$. When we compared donors with vs without TLOs we found no significant differences in the positivity rates for each $\mathrm{aAb}$ (GAD aAb [GADA], tyrosine phosphatase-related islet antigen $2 \mathrm{aAb}$ [IA-2A], zinc transporter $8 \mathrm{aAb}$ [ZnT8A]; excluding insulin $\mathrm{aAb}$ [IAA], not tested) or for multiple aAbs (ESM Fig. 5) by Fisher's exact test.
Fig. 1 TLOs in human donors with type 1 diabetes. $(\mathbf{a}, \mathbf{b})$ Representative images of a heavily inflamed $\left(\mathrm{CD} 45^{+}\right)$insulin-positive islet in periinsulitis stage (donor no. 6325) (a) with intermixed T cells and B cells (b). PLM marks the peri-islet BM, endothelial BM of blood vessels and acinar BM (a) and a consecutive section stained for T cells $\left(\mathrm{CD}^{+}\right), \mathrm{B}$ cells $\left(\mathrm{CD} 20^{+}\right)$and collagen type III shows the RFs (b); boxed area is shown at higher magnification. (c) Representative image of a heavily inflamed islet characterised by disruption of peri-islet $\mathrm{BM}\left(\mathrm{PLM}^{+}\right)$by infiltrating immune cells $\left(\mathrm{CD} 45^{+}\right)$. The arrow marks intact peri-islet $\mathrm{BM}$ and the arrowhead marks disrupted peri-islet BM; boxed area is shown at higher magnification. (d, e) Visualisation of a heavily inflamed insulin-positive islet with $\mathrm{T}$ cell and B cell compartments (donor no. E124B). Collagen VI marks the interstitial matrix of the islet and surrounding exocrine tissue, CD45 labels all leucocytes (d). Immunofluorescence staining for CD3 and CD20 reveals T cell and B cell compartments and MECA79 staining identifies HEVs (arrows) in the T cell zone (e). (f, g) Frequency of TLOs in relation to the age at diabetes diagnosis $(\mathbf{f}, * p<0.05)$ and disease duration $(\mathbf{g}, p=0.3)$. (h) Proportion of islets with TLOs in relation to disease severity, which was defined by assigning the islets into four phases based on their insulin content and on the presence of insulitis: phase 0 (insulin-positive islets without insulitis); phase 1 (insulin-positive islets with insulitis); phase 2 (insulin-negative islets with insulitis); and phase 3 (insulin-negative islets without insulitis). There was a statistically significant difference across these groups using the Kruskal-Wallis test $(* * * p<0.001)$. Proportion of islets with TLOs in donors with compartmentalised (TLOs Comp.) and intermixed TLOs (TLOs Int.) $(p=0.2)$ (i). There was no difference in age at diagnosis among donors classified by TLO stages $(p=0.1090$, Kruskal-Wallis test) (j) but disease duration was different $(* p<0.05$, Kruskal-Wallis test) $(\mathbf{k})$. Scale bars, $100 \mu \mathrm{m}$, or $50 \mu \mathrm{m}$ for areas of higher magnification. Data are shown as means \pm SD in all graphs. Coll, collagen; is, islet

\section{Potential TLOs in the human pancreas with islet autoimmu-} nity from $\mathrm{aAb}^{+}$donors without diabetes Among the organ donors positive for one or two aAbs, insulitis was observed in $1 / 7$ and $3 / 6$ samples, respectively, and was associated with insulin-positive islets in all donors examined. In the three double- $\mathrm{AAb}^{+}$donors with insulitis, we performed triple staining for PLM, CD45 and insulin (Fig. 2a) or for CD45, PLM and MECA79 (Fig. 2b). The latter revealed peri-islet CD45 ${ }^{+}$ immune cell aggregates surrounding MECA79 ${ }^{+} \mathrm{HEVs}$, suggesting the existence of TLOs. Given the limited number of pancreas sections available, we could not perform CD3/ $\mathrm{CD} 20$ staining for $\mathrm{aAb}^{+}$donors. However, the staining combinations allowed us to demonstrate insulitis and the presence of TLOs, which by their features we consider to be immature. Such leucocyte aggregates and MECA79 ${ }^{+} \mathrm{HEVs}$ were not detected in the single-aAb $\mathrm{A}^{+}$donor with insulitis, in which we analysed 29 islets with insulitis. No beta cell loss was apparent in any of the $\mathrm{aAb}^{+}$donors.

\section{TLOs in pancreas of recipients who experienced recurrent} type 1 diabetes following the transplant We previously reported that about 5-6\% of individuals with type 1 diabetes who receive SPK transplantation develop recurrence of disease in the transplanted pancreas; this typically occurs several years after transplantation despite chronic immunosuppression and in the absence of clinical rejection [20, 21]. 

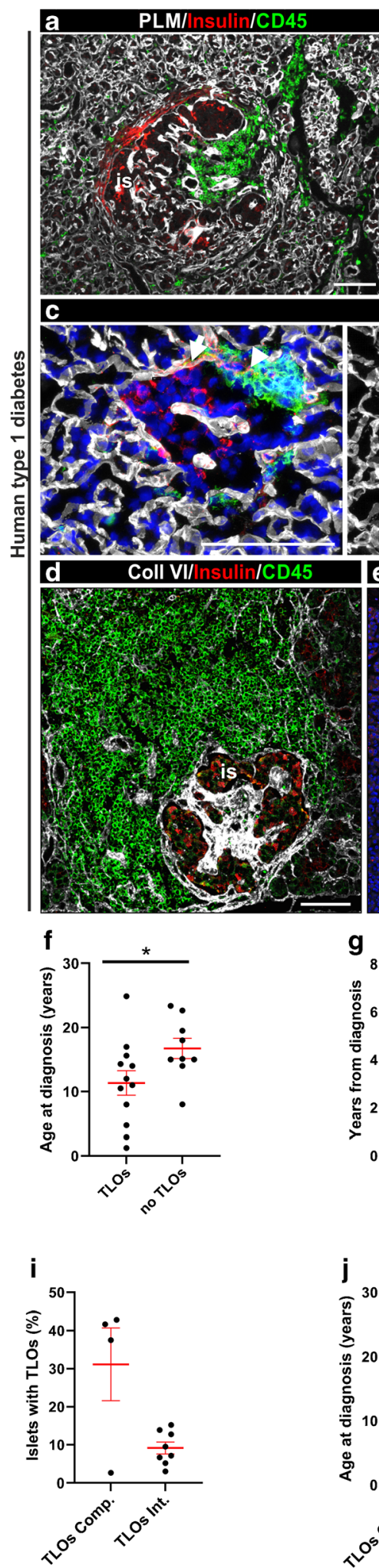

b CD3/CD20/Coll III

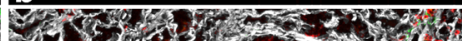
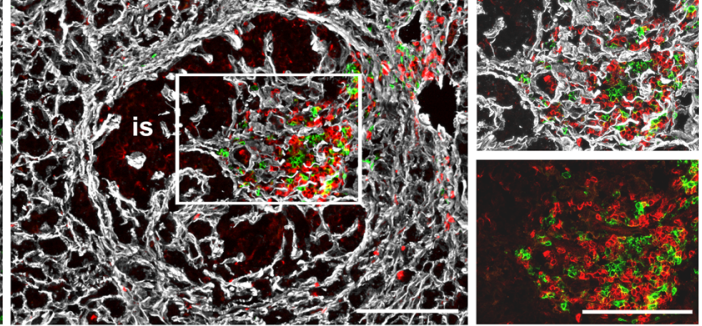
PLM/Insulin/CD45/
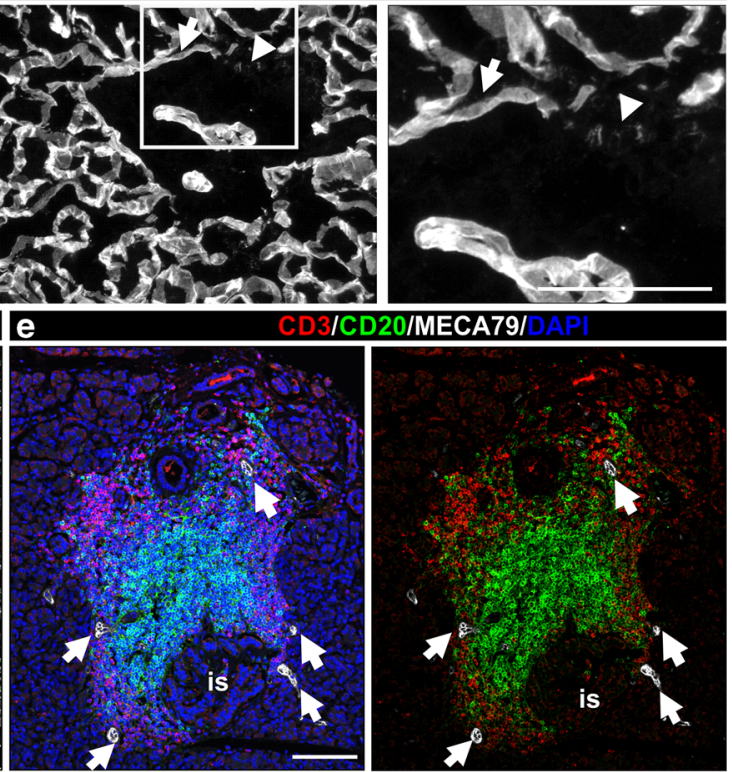

h

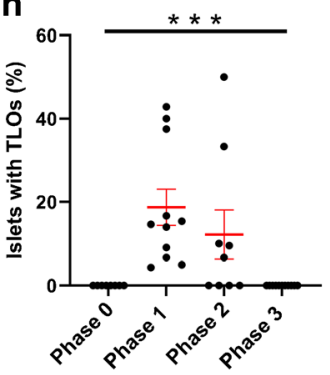

k

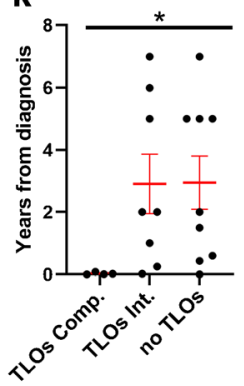

Here, we examined biopsies containing insulin-positive islets and exhibiting insulitis from three transplant recipients in whom evidence of acute pancreas rejection was lacking (Table 2) [20, 21]. TLOs were detected in all three biopsies. Immunofluorescence staining for collagen III and CD45 or
CD20 and CD3 revealed leucocyte infiltration around insulin-positive islets (Fig. 3a, b) that was associated with platelet-derived growth factor receptor $\beta$ (PDGFr $\beta$ ) staining (Fig. 3b). All three biopsies showed some degree of T cell and B cell organisation (Fig. 3a); in one sample (from donor no. 


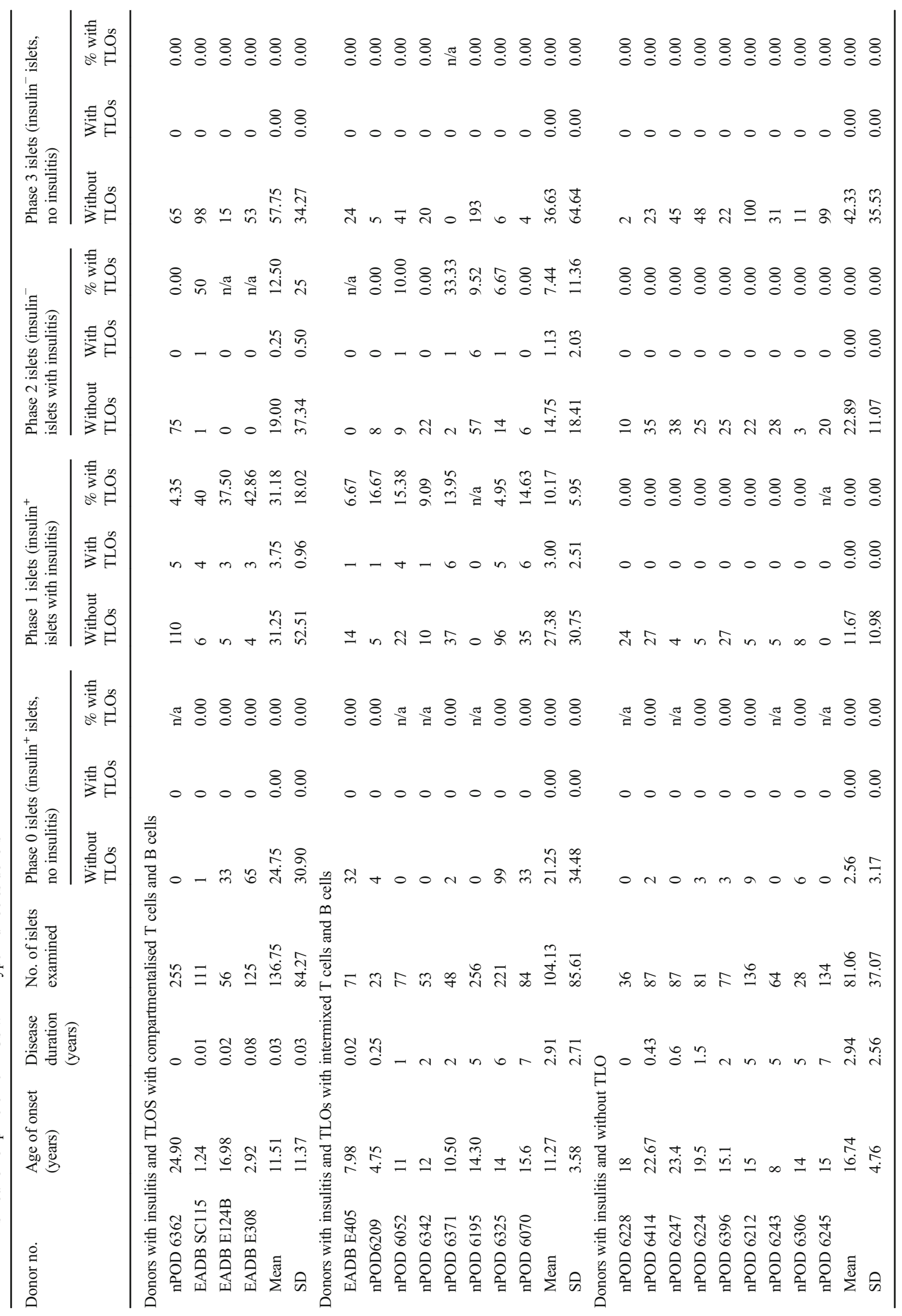


3678) we detected B cell follicle-like structures surrounded by $\mathrm{T}$ cells in close association with pancreatic ducts (Fig. 3c). We detected PDGFr $\beta^{+}$FRCs surrounding the RFs (Fig. 3d) and MECA79 ${ }^{+}$HEVs (Fig. 3e, f) in the T cell areas.

TLOs associated with pseudo-atrophic islets and pancreatic ducts In five donors with type 1 diabetes (no. 6052, no. 6195 , no. 6325 , no. SC115 and no. 6371), TLOs were detected in association with insulin-negative pseudo-atrophic islets (Fig. 4a, ESM Fig. 4d) and in close association with pancreatic ducts containing insulin-positive cells (Fig. 4b-d). The insulin-positive cells in the duct showed some co-staining for CK19, a marker of epithelial ductal cells (Fig. 4c). No islets were detected in close vicinity to the ducts and there was no indication of pancreatitis based on histological characterisation by nPOD. Duct-associated TLOs had mostly T cells and little or no CD20 $0^{+} \mathrm{B}$ cells (Fig. 4e). Dense collagen $\mathrm{III}^{+} / \mathrm{ERTR}^{+}$RFs associated with PDGFr $\beta^{+}$cells were observed in the $\mathrm{T}$ cell infiltrates (Fig. 4f). Furthermore, MECA79 ${ }^{+}$HEVs were identified at sites of leucocyte accumulation in the wall of the pancreatic duct (Fig. 4g).

Characteristics of TLOs in the human pancreas with islet autoimmunity compared with NOD mice Comparisons between mouse and human TLOs revealed similarities and differences. All stages of TLOs and insulitis could be detected in 14-weekold NOD mice [22], ranging from intermixed $\mathrm{T}$ cells and $\mathrm{B}$ cells (Fig. 5a) to well-organised $\mathrm{T}$ cell and $\mathrm{B}$ cell compartments (Fig. 5b, c) with a dense RF network in the T cell zone (Fig. 5c), as also occurs in mouse LNs (ESM Fig. 6). In contrast, infiltrating $\mathrm{T}$ cells and $\mathrm{B}$ cells were intermixed in most of the human pancreas samples with islet autoimmunity and TLOs with T cell and B cell compartments were rarely detected (detected in 4/12 donors) (Table 3, Fig. 1d, e and ESM Fig. 4).
Characteristics of RFs in the human pancreas with islet autoimmunity compared with NOD mice Studies in LNs have revealed a well-organised RF network composed of RFs and FRCs $[8,13,27]$, which provides physical and functional support for immune cells (ESM Fig. 6) [28]. The same features were described in pancreatic TLOs of NOD mice [17]. RFs of NOD mice and human pancreatic TLOs stained for BM molecules and fibrillar collagen type III (Fig. 5a-g). TLOs contained a filigree RF network, as shown by laminin $\alpha 4$ and PLM staining in mouse (Fig. 5a-d) and human samples (Fig. 5g, h), HEVs defined by MECA79 staining (Fig. 5e, h), and a thick BM [8] (Fig. 5b, h). Electron microscopy of an inflamed NOD mouse islet confirmed the presence of fibrillar collagen bundles in the RF core, covered by a thin $\mathrm{BM}$ and surrounded by lymphocytes and FRCs (Fig. $5 \mathrm{f}$ and ESM Fig. 7), consistent with studies of LNs [8]. We conducted in-depth characterisation of the structural components of RFs in NOD mice (ESM Results and ESM Fig. 8) using a large repertoire of antibodies specific for ECM molecules (ESM Table 1). RFs in inflamed human islets have the same basic structure as RFs of pancreatic TLOs in NOD mice.

Conduit function of RFs RFs of LNs can act as conduits for the rapid transport of soluble, low-molecular-weight molecules such as chemokines and antigens $[8,13]$. We investigated whether the RFs of pancreatic TLOs have a similar function. Tracer experiments using FITC-labelled dextran and immunofluorescence staining for chemokines and insulin (as antigen) support a potential conduit function of RFs in pancreatic TLOs, similar to their function in LNs (ESM Results and ESM Fig. 9).

FRCs in pancreatic TLOs Several FRC markers have been described, including PDGFr $\beta$ and podoplanin; the latter is also a lymphatic marker [29]. Triple staining of human
Fig. 2 Potential TLOs in preclinical human donors with type 1 diabetes. Representative images of a double- $\mathrm{aAb}^{+}$donor (no. 6197) with insulin-positive inflamed islet stained for PLM, insulin and CD45 (a) or MECA79, PLM and CD45 (b). Arrows mark the disruption of peri-islet BM in (a) and the MECA79 $9^{+}$HEV s in (b). Arrowheads point to MECA79vessels. Scale bars, $100 \mu \mathrm{m}$ (a) and $50 \mu \mathrm{m}(\mathbf{b})$. ac, acini; fa, fat; is, islet
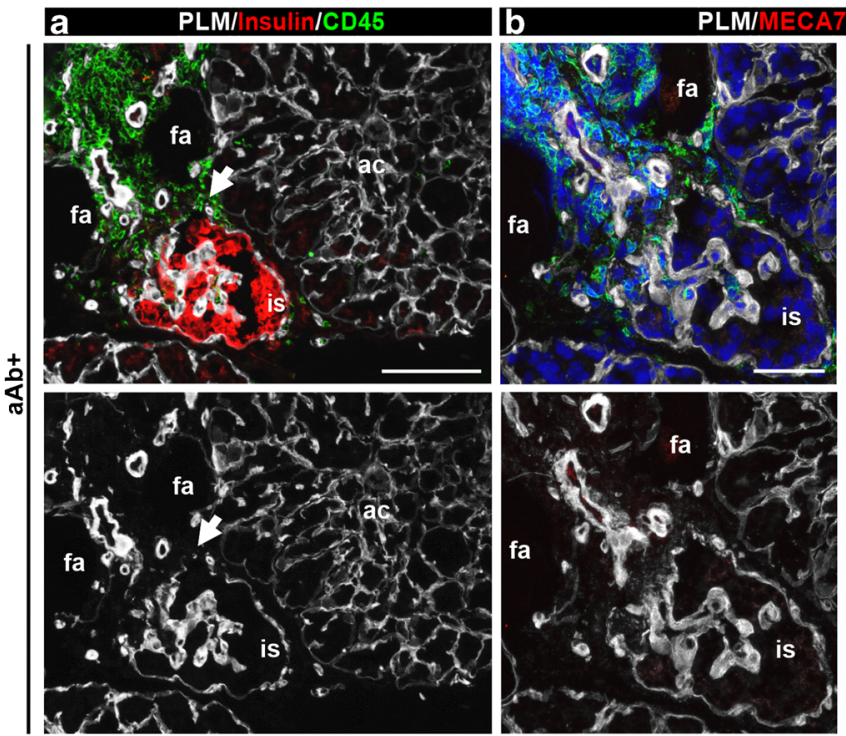

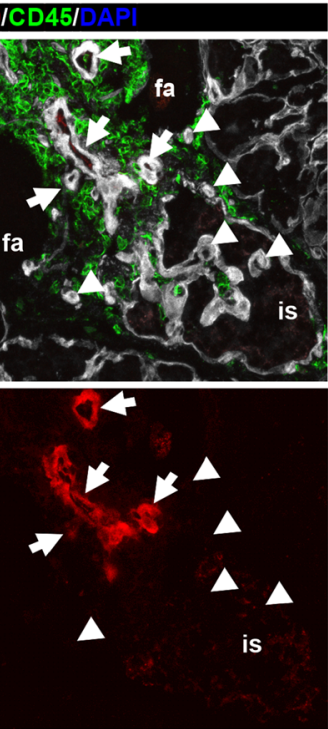


Fig. 3 TLO detection in pancreas transplanted into recipients in whom recurrent type 1 diabetes developed. (a, b) Representative immunofluorescence images of pancreatic TLOs associated with islets in a biopsy sample (donor no. 3678). Triple immunofluorescence staining for $\mathrm{CD}^{+} \mathrm{T}$ cells, $\mathrm{CD} 20^{+} \mathrm{B}$ cells and collagen III for RFs (arrows) and the interstitial matrix of the islet and exocrine pancreas are shown (a). A parallel section was stained for PDGFr $\beta^{+}$FRCs associated with the collagen $\mathrm{III}^{+} \mathrm{RFs}(\mathbf{b})$; CD45 staining marks leucocytes. Boxed areas are shown at higher magnification. (c, d) Triple immunofluorescence staining using the same antibody combination as in (a) and (b) reveals TLO in the wall of the pancreatic duct. Boxed area is shown at higher magnification. (e, f) Triple staining for PLM, MECA79 and CD45 or CD31 revealing MECA79 staining of HEVs (arrowheads) and of some epithelial cells in the pancreatic ducts (arrows). Scale bars, $50 \mu \mathrm{m}$ $(\mathbf{a}-\mathbf{c}, \mathbf{e}, \mathbf{f})$ or $25 \mu \mathrm{m}$ (inset in $\mathbf{b}, \mathbf{d}$ ). Coll, collagen; du, duct; fo, follicle
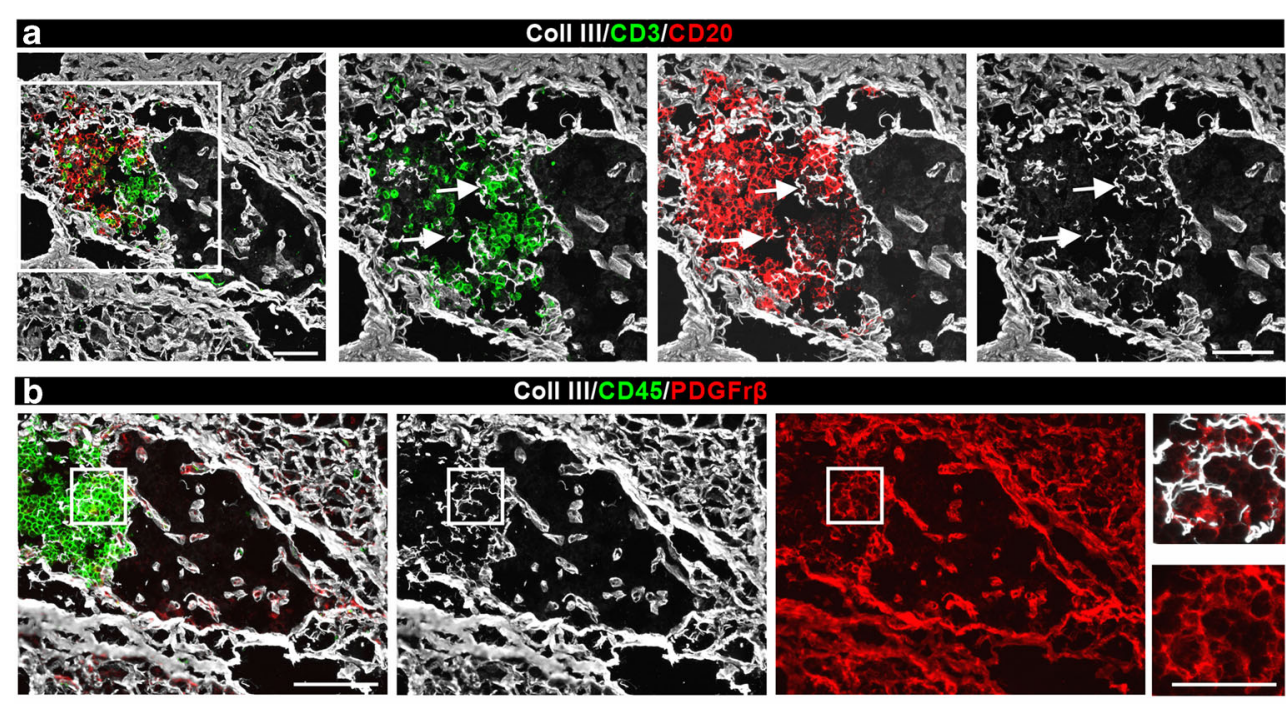

Coll III/CD45/PDGFr!
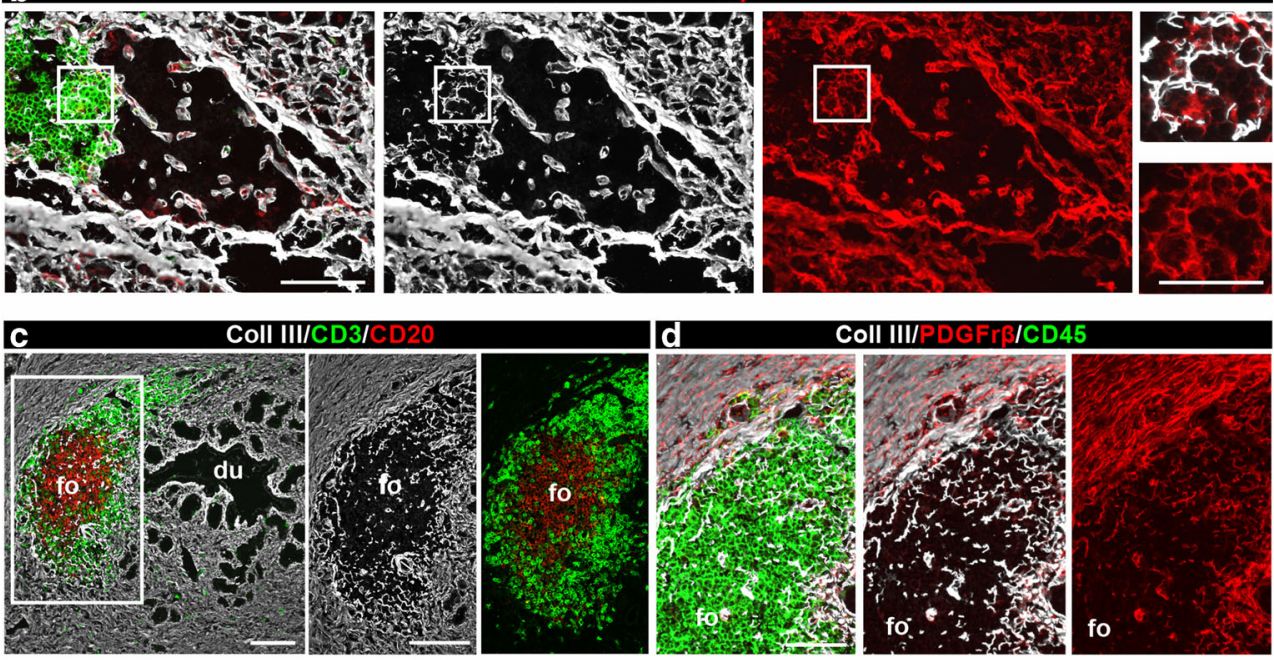

Coll III/PDGFrß/CD45
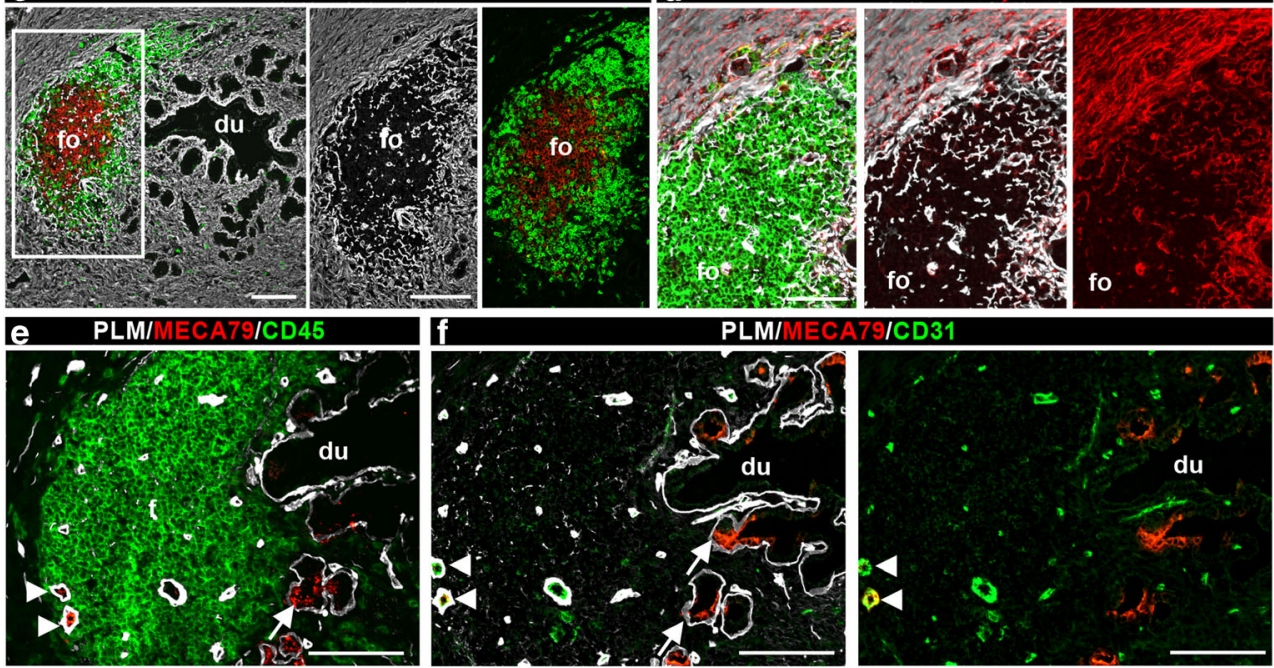

IICD31

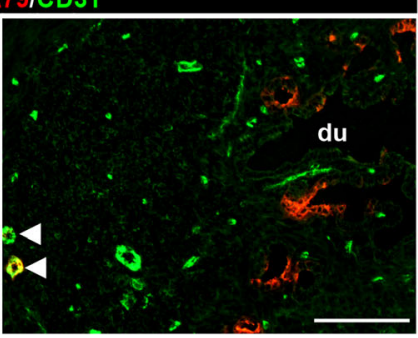

samples revealed a strong PDGFr $\beta$ signal within $\mathrm{CD} 45^{+}$infiltrates where it occurred surrounding the collagen III RFs (Fig. 6a), consistent with the location of FRCs in mouse pancreatic TLOs (Fig. 6b) and LNs [17, 29]. Podoplanin staining was limited to lymphatic vessels (not shown) in NOD mouse and human pancreases but was present in inflamed islets in pancreases of both humans with type 1 diabetes (Fig. 6c) and NOD mice (Fig. 6d). Our data suggest that stromal cells associated with RFs in human pancreatic TLOs are similar to FRCs described previously in LNs and TLOs of NOD mice.

Immune cell subtypes and proliferating cells in pancreatic TLOs In the four type 1 diabetes samples exhibiting compartmentalisation of $\mathrm{T}$ cells and $\mathrm{B}$ cells in association with insulin-positive (from donors no. 6362, no. E308 and no. E124B) and insulin-negative islets (from donor no. SC115) (Table 3 and ESM Fig. 4), the T cell compartment contained a dense RF network visualised by collagen VI staining and the B cell zone showed less-dense RFs and the presence of CD21 ${ }^{+}$FDCs (Fig. 7a and ESM Fig. 4), similarly to inflamed islets from NOD mice (Fig. 7b). FDCs are nonmigratory cells associated only with B cell follicles in LNs [30]; their detection suggests the formation of germinal centres and propagation of the immune response [31]. Therefore, we investigated immune cell subtypes that are indicative of an ongoing inflammatory reaction: $\mathrm{CD} 138^{+}$plasma cells were detected in human TLOs scattered throughout $\mathrm{CD} 45^{+}$areas (Fig. 7c), in close proximity to islets (Fig. 7d); memory T cells $\left(\mathrm{CD}_{4} \mathrm{RO}^{+}\right.$) were abundant (Fig. 7e); forkhead box P3 $(\mathrm{FOXP} 3)^{+}$regulatory $\mathrm{T}$ cells were rarely detected (none, or one or two $\mathrm{FOXP}^{+}$cells/TLO, Fig. $7 \mathrm{e}$ ). Few $\mathrm{Ki} 67^{+} / \mathrm{CD} 45^{+}$ proliferating cells were found in inflamed human islets (Fig. 7f). Plasma cells and memory $T$ cells were also detected in NOD mouse samples [32, 33], similarly to Ki67 $7^{+}$cells (Fig. $7 \mathrm{~g}$ ) and $\mathrm{FOXP}^{+}$(Fig. 7h), which were abundant in inflamed mouse islets, consistent with earlier reports [32, 33]. Quantification within the inflamed islet from donor no. 6362 (Fig. 7) shows $6 \%$ plasma cells, $0.5 \%$ FOXP3 $^{+} \mathrm{T}$ cells, $53 \%$ 
Fig. 4 TLOs associated with insulin-negative islets and with the wall of pancreatic ducts in human type 1 diabetes. (a, d) Representative

immunofluorescence images of pancreas sections (from donor no. 6195) triple-stained for insulin, PLM and CD45 showing inflamed pancreatic islet (a) and pancreatic duct (d). Arrows point to RFs (a) and to insulin-positive cells in the pancreatic duct (d). (b) Low magnification image of a consecutive section of the duct stained for BM marker perlecan and DAPI to visualise the surroundings of the inflamed duct. There was no islet detected in close vicinity to the duct. (c) Triple immunofluorescence for CK19, insulin and laminin $\alpha 5$ to mark ductal epithelial cells, beta cells and BMs, respectively. Boxed area is shown at higher magnification. Arrows in (c) mark insulin-positive cells among the pancreatic duct epithelial cells. (e) Immunofluorescence staining of pancreatic duct for $\mathrm{CD}^{+} \mathrm{T}$ cells, $\mathrm{CD} 20^{+} \mathrm{B}$ cells and collagen type III to mark RFs. (f) Double staining of pancreatic duct for PDGFr $\beta^{+}$and ERTR7. Note the different PDGFr $\beta$ staining pattern at sites of leucocyte accumulation (dashed line) compared with the non-inflamed region of the duct (star). (g) Staining for MECA79 reveals HEVs (arrows) in inflamed pancreatic duct and some signal on the surface of the duct epithelium. Scale bars, $100 \mu \mathrm{m}(\mathbf{a}, \mathbf{b}, \mathbf{d}) ; 50 \mu \mathrm{m}(\mathbf{c}, \mathbf{e}-\mathbf{g}$; and $\mathbf{d}$ [area shown at higher magnification]) or $25 \mu \mathrm{m}$ (c [area shown at higher magnification]). Coll, collagen; du, duct; is, islet; rf, RFs
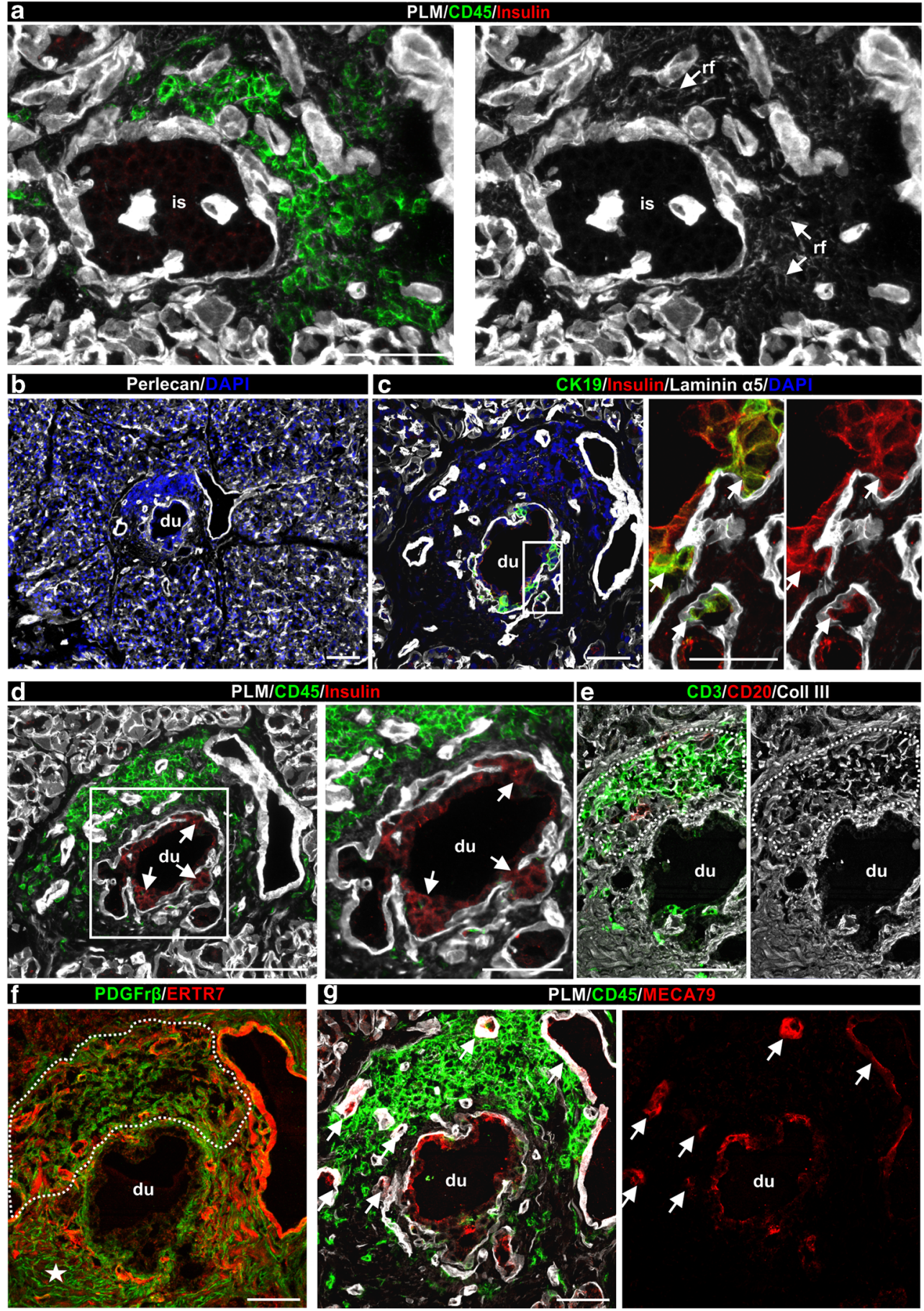

memory $\mathrm{T}$ cells and $2 \% \mathrm{Ki} 67^{+}$cells among the $\mathrm{CD} 45^{+}$cells. These results suggest that TLOs may contribute to the longterm perpetuation of inflammation in human type 1 diabetes.

\section{Discussion}

Previous studies associated pancreatic TLOs with type 1 diabetes in NOD mice $[15,16]$. An earlier investigation failed to identify these structures using immunofluorescence staining for $\mathrm{CD} 4^{+} \mathrm{T}$ cells and $\mathrm{CD} 19^{+} \mathrm{B}$ cells in pancreases donated by four humans with type 1 diabetes (12-22 years old, 18 years of diabetes duration) [15]. Recently, TLOs were described in the pancreas of a single person with long disease duration [18]. Our study is the first to systematically examine pancreatic TLOs in a cohort of donors $(n=37)$ at distinct stages of islet autoimmunity. We provide definitive evidence for the existence of TLOs in the human pancreas of 
Fig. 5 Comparison of pancreatic TLOs in NOD mouse and human type 1 diabetes samples. (a-c) Triple immunofluorescence staining of 14-week-old NOD mouse pancreases for $\mathrm{CD} 3$ to label T cells, CD20 to mark B cells and laminin $\alpha 4$ to mark the islet BMs, acinar BMs and the BM of RFs revealed $\mathrm{B}$ cells and $\mathrm{T}$ cells intermixed (a) and compartmentalised TLOs (b, c). Dashed lines mark $T$ cell areas, stars mark B cell zones; arrowheads label HEVs and arrows mark RFs. 'is' indicates the healthy part of the islet. (d, g) Immunofluorescence staining for collagen III to label the core of RFs and PLM to mark BMs of inflamed islets of NOD mouse (d) and human type 1 diabetes samples (g). Arrowheads point to HEVs and arrows indicate the RFs (d). Boxed areas are shown at higher magnification. (e, h) MECA79 staining reveals HEVs in pancreas from NOD mouse (e, arrowhead) and human type 1 diabetes samples (h). All blood vessels are marked either with MECA32 (e) or CD31 (h) and PLM stains the BM of RFs and pancreatic islets. (f) Electron micrograph of an inflamed islet shows the ultrastructure of HEV (box 1) and of RFs (box 2). FRCs (pseudo-coloured in cyan) and lymphocytes (pseudo-coloured in violet) closely associate with RFs (box 2), which is shown at higher magnification in box 3 ; asterisk labels the inner collagen fibres and arrows mark the outer BM. The same micrograph with grid is shown in ESM Fig. 7. Boxed area is shown at higher magnification. Scale bars, $100 \mu \mathrm{m}(\mathbf{a}-\mathbf{c}), 50 \mu \mathrm{m}$ $(\mathbf{d}, \mathbf{e}, \mathbf{g}, \mathbf{h}), 25 \mu \mathrm{m}(\mathbf{d}, \mathbf{e}$ [areas shown at higher magnification]), $5 \mu \mathrm{m}$ (f [boxes 1 and 2]) or $500 \mathrm{~nm}$ (f [box 3]). ac, acini; Coll, collagen; $\mathrm{EM}$, electron micrograph; is, healthy islet; rf, RFs

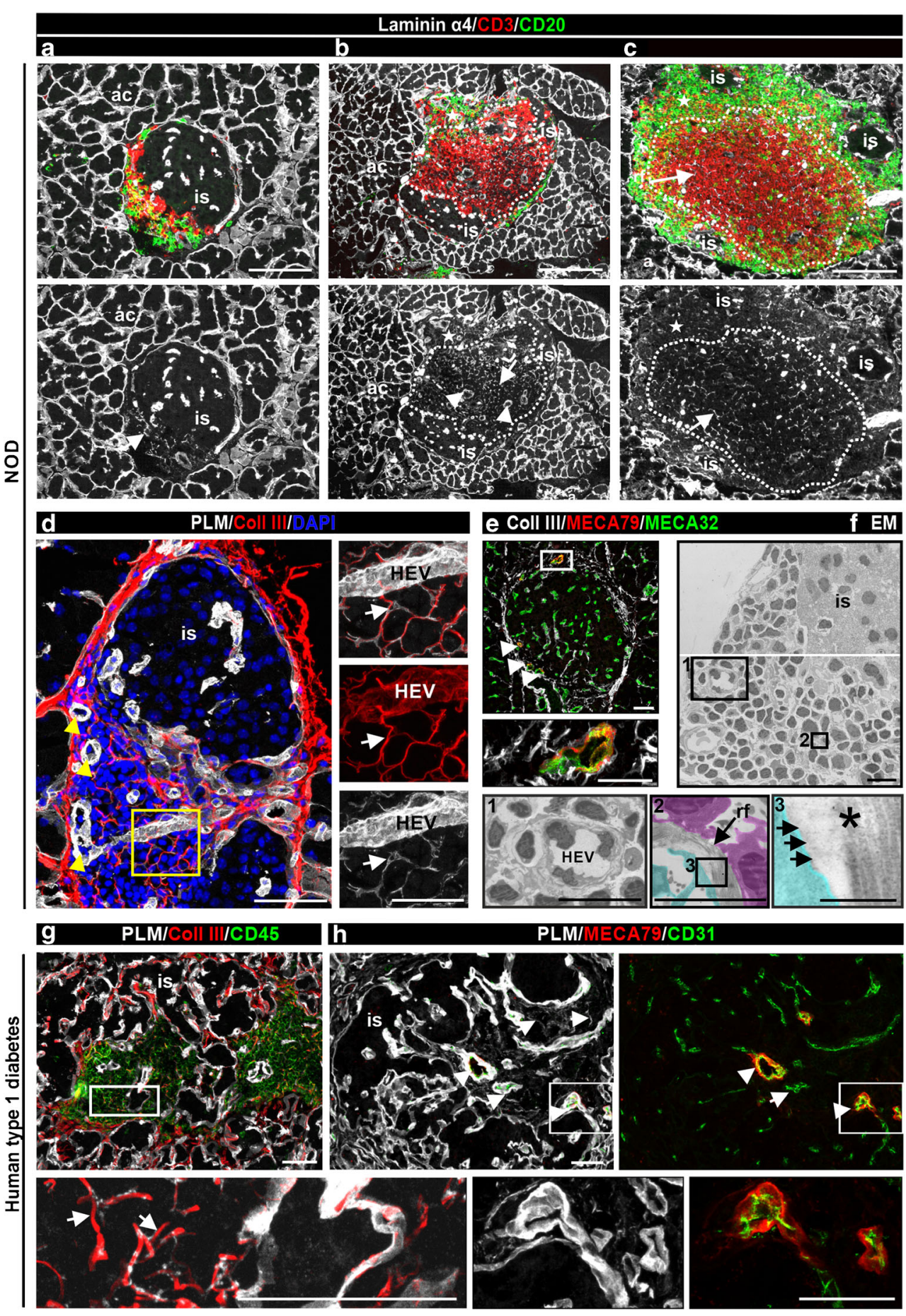

individuals at high risk of diabetes, at/after diagnosis, and in pancreases of recipients who experienced recurrent type 1 diabetes after transplantation. The clear identification of TLOs in our study also arises from the assessment of multiple ECM components of the RF network, different leucocyte types, stromal cells and specialised endothelial markers. However, TLO positive islets are a rare event and as such the comparisons between different groups described in this study should be interpreted with caution. Collectively, our data suggest that the occurrence of TLOs correlates with leucocyte infiltrates surrounding mostly insulin-positive islets. We also show several structural similarities between LNs and the pancreatic TLOs, and between TLOs in human and NOD mouse pancreases. The findings support the concept that TLOs in the pancreas of individuals with islet autoimmunity/type 1 diabetes may support recruitment and activation of lymphocytes from the circulation and thereby promote disease progression. 


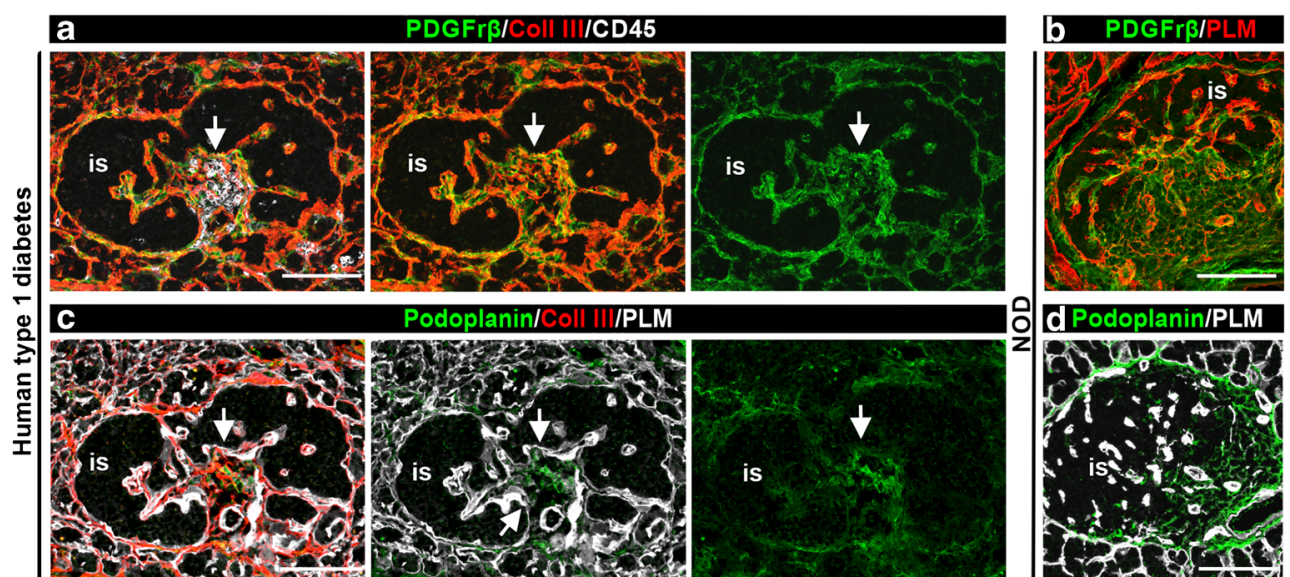

Fig. 6 Comparison of fibroblastic reticular cell markers in pancreatic TLOs in NOD mouse and human type 1 diabetes samples. (a, c) Immunofluorescence staining of inflamed human pancreas (donor no. 6325) for collagen III, PDGFr $\beta$ and CD45 (a) or collagen III, podoplanin

A strength of our study is that we could examine pancreas tissue from donors with recent-onset type 1 diabetes, residual insulin-positive islets and ongoing autoimmunity. We examined 24 donors with clinical type 1 diabetes, most of whom were selected for having insulitis (21/24) and several of whom had very short disease duration. Among the 21 type 1 diabetes samples exhibiting insulitis, 12 contained TLOs; the donors of samples with TLOs were diagnosed at a significantly younger age than those without TLOs, while disease duration was not statistically different. We also show that TLOs form in the transplanted pancreas in recipients with recurrent type 1 diabetes, suggesting that they may contribute to reappearance of the disease in these individuals, who also had circulating autoreactive $\mathrm{T}$ cells and autoantibodies despite chronic immunosuppression to prevent rejection [20,34].

The detection of insulitis and TLOs in a significant proportion of multiple autoantibody-positive donors suggests that TLO formation may precede clinical diagnosis, as in NOD mice, and supports a role for TLOs in promoting inflammation at early stages of diabetes. Given the extreme rarity of donors with a single $\mathrm{aAb}$ and insulitis, we cannot determine whether TLOs are present at this stage.

Insulitis among the donors with islet autoimmunity was not as extensive as the insulitis observed in NOD mice; this finding was expected, based on earlier comparisons of mouse and human pancreas pathology $[35,36]$. TLOs in human samples mostly resembled those seen in NOD mice exhibiting mild insulitis, where the immune cells accumulated around the islets (peri-insulitis) and T cells and B cells were intermixed. Consequently, the typical features of TLOs, such as HEVs, RF network and the intermixed $\mathrm{T}$ cells and $\mathrm{B}$ cells, were mostly localised to peri-islet areas. TLOs were mainly associated with inflamed insulin-positive islets and their frequency was decreased in inflamed insulin-negative islets; they were not associated with insulin-negative, pseudo-atrophic islets and PLM (c). (b, d) Immunofluorescence staining of NOD mouse pancreases for PLM and PDGFr $\beta$ (b) or podoplanin (d). Arrows mark accumulation of FRCs at site of inflammation. Scale bars, $100 \mu \mathrm{m}$. Coll, collagen; is, healthy part of the islet

lacking insulitis, and were not found in three donors with long disease duration (>30 years) who lacked insulitis and insulinpositive islets. All these data support a role for TLOs in the early stages of disease and in disease progression.

While most of the donors exhibited intermixed TLOs, four donors exhibited compartmentalised TLOs; two of the latter were at a particularly young age when diagnosed with diabetes (1.24-2.92 years). Disease duration was significantly shorter in these four donors compared with those with only intermixed T cells and B cells and those without TLOs, raising the possibility that compartmentalised TLOs are a feature of recent-onset type 1 diabetes and/or aggressive disease progression. Compartmentalised TLOs also exhibited structures closely resembling B cell follicles, as suggested by the presence of an FDC network surrounded by $\mathrm{T}$ cells and the presence of plasma cells and memory $\mathrm{T}$ cells. In addition, nuclear staining revealed areas of high and low cellular density within the B cell aggregates, consistent with the dark and light zones of germinal centres, respectively [37]. These data are consistent with published data showing a correlation between the presence of B cells in islet infiltrates in young donors with type 1 diabetes [38] and with the reported more aggressive disease progression in young individuals [39].

Tracer experiments performed in NOD mice confirmed that RFs in the TLOs were capable of transporting fluid, as described for LNs [8] and RIP-CXCL13 mice [17]. Autoantigen (insulin) and chemokines (CCL21) were detected within the RFs in NOD pancreases, supporting a conduit function for the RFs in the pancreatic TLOs. We were not able to detect chemokine or antigen in the RFs of human pancreatic TLOs. CCL21 was observed just on the surface of MEC79 ${ }^{+}$ HEVs; this could be due to the differences between species, low expression level and/or quality of the samples.

TLOs were found in proximity to pancreatic ducts in samples from insulin-negative, pseudo-atrophic islets lacking 
Fig. 7 Comparison of FDCs and immune cell subtypes in pancreatic TLOs in NOD mouse and human type 1 diabetes samples. (a, b) Triple

immunofluorescence staining for CD21, CD20 and insulin (a), or PLM, CD21 and DAPI (b) reveals CD21 ${ }^{+}$FDCs in B cell follicles in inflamed human (donor no. E124) (a) and NOD mouse islets (b), dashed line marks the B cell compartment. (c-e) Triple immunofluorescence staining of consecutive sections of an extensively inflamed insulin-positive islet (donor no. 6362) for PLM, CD45 and insulin (c), collagen III, CD138 to mark plasma cells and CD21 to label FDCs (d) and PLM and FOXP3 to mark regulatory $\mathrm{T}$ cells and CD45RO to mark memory T cells (e). Star indicates the B cell follicle (c) and arrow points to FOXP3+ regulatory T cell (e, inset). Boxed areas are shown at higher magnification. (f, $\mathbf{g}$ ) Immunofluorescence staining for the proliferation marker Ki67, CD45 and laminin $\gamma 1$ to mark all BMs of human (donor no. 6362) (f) and NOD mouse (g) inflamed islets reveals few proliferating immune cells. (h) FOXP3 staining of NOD mouse samples reveals regulatory $\mathrm{T}$ cells. Scale bars, $50 \mu \mathrm{m},(25 \mu \mathrm{m}$ for areas shown at higher magnification). Coll, collagen; is, islet
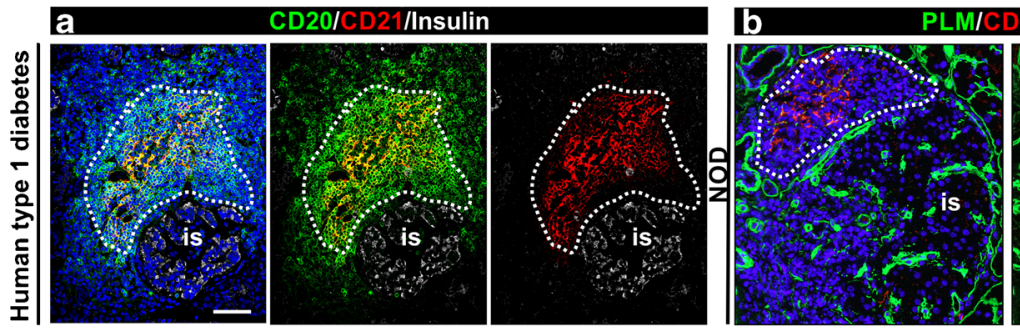

LLM/CD21/
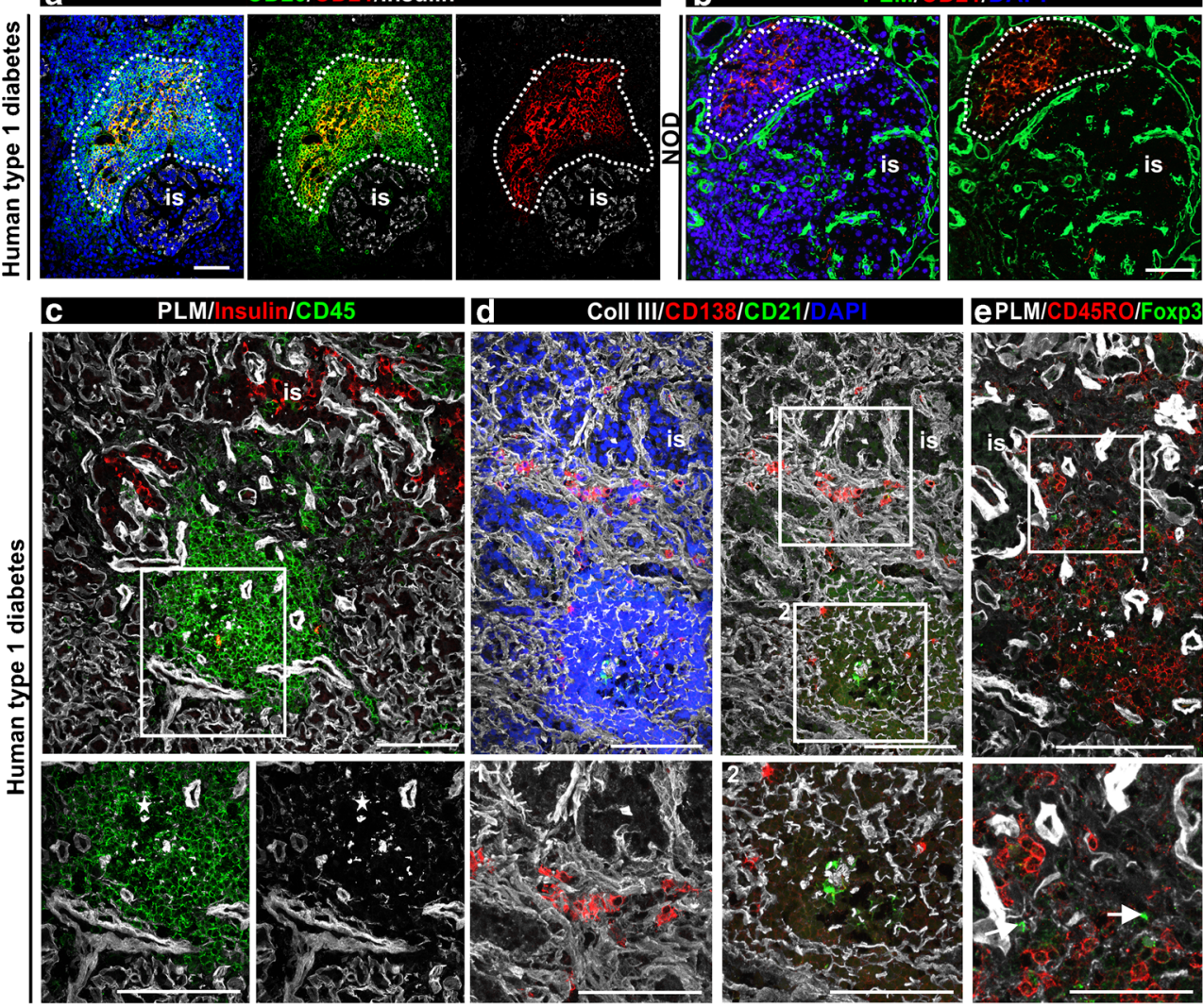

ePLM/CD45RO/Foxp3
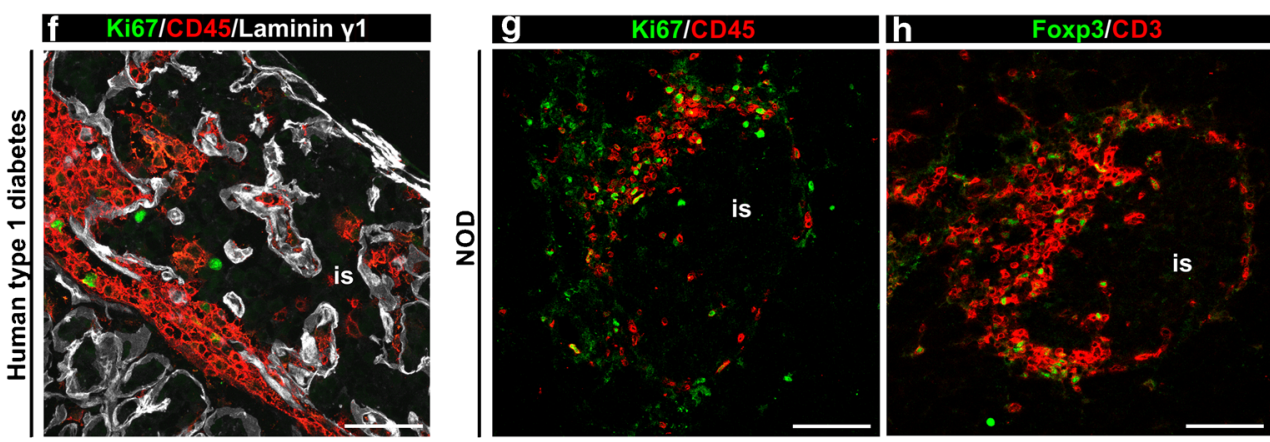

insulitis and in the pancreas transplant biopsies, with an associated expression of insulin in ductal epithelial cells in the former case. We have previously observed insulin-positive ductal cells in pancreas transplant biopsies where there is recurrent type 1 diabetes [40]. It is plausible that insulinpositive cells in the ducts may represent regenerative or trans-differentiation events [40], which may attract an autoimmune infiltrate and recapitulate certain aspects of disease development, including TLO formation.

In conclusion, we demonstrate pancreatic TLOs at different stages of human type 1 diabetes and describe similarities and differences when compared with pancreatic TLOs in NOD mice. TLOs in the human pancreas with type 1 diabetes appear at sites of active autoimmunity but are not detected once the destructive process has run its course. These data are consistent with studies in NOD mice showing that TLOs disappear once beta cells, the antigen source, perish [15]. Importantly, the presence of TLOs in preclinical organ donors exhibiting insulitis suggests that they form before development of clinical symptoms and supports their role in disease progression. Further studies should refine the characterisation of immune subtypes within the TLOs and investigate the presence of autoantigen-specific plasma cells and $\mathrm{T}$ cells, as these may vary by stage and severity.

Supplementary Information The online version contains peer-reviewed but unedited supplementary material available at https://oi.org/10.1007/ s00125-021-05453-z.

Acknowledgements This work was performed with the help of the nPOD (RRID: SCR_014641), a collaborative type 1 diabetes research project sponsored by JDRF (nPOD: 5-SRA-2018-557-Q-R) and the Leona M. \& Harry B. Helmsley Charitable Trust (grant no. 2018PG-T1D053). The content and views expressed are the responsibility of the authors and do 
not necessarily reflect the official view of nPOD. Organ Procurement Organizations (OPO) partnering with nPOD to provide research resources are listed at http://www.jdrfnpod.org/for-partners/npod-partners. We are thankful to nPOD and EADB for providing us with precious donor samples. We are grateful to organ donors and their families. We are thankful to M.-J. Hannocks (Institute of Physiological Chemistry and Pathobiochemistry, University of Muenster, Germany) for critical reading of the manuscript.

Data availability Further information about the data are available from the corresponding author upon request.

Funding Open Access funding enabled and organized by Projekt DEAL. This work was supported by the European Foundation for the Study of Diabetes (ZUW80166) and the Leona T. Helmsley Charitable Trust George Eisenbarth Award for nPOD Team Science (2015PG-T1D052).

Authors' relationships and activities The authors declare that there are no relationships or activities that might bias, or be perceived to bias, their work.

Contribution statement ÉK acquired most of the data and together with LS contributed to conception, design of the experiments, interpretation of data and writing the manuscript. SL and CF contributed to acquisition of data and revised the article. NK was involved in interpretation of data and revised the manuscript. FA acquired the electron microscopy data and revised the manuscript. SR and NM provided samples from EADB, interpreted the data and revised the manuscript. $\mathrm{MB}$ and $\mathrm{AP}$ contributed to data analysis, data interpretation and revision of the article. AP and GWB identified the pancreas transplant recipients described in this study and conducted initial clinical and pathology characterisation. LS conceived the project, supervised the project and contributed to writing the manuscript. All authors critically reviewed and approved the final version of the manuscript. LS is the guarantor of this work and, as such, had full access to all the data in the study and takes responsibility for the integrity of the data and the accuracy of the data analysis.

Open Access This article is licensed under a Creative Commons Attribution 4.0 International License, which permits use, sharing, adaptation, distribution and reproduction in any medium or format, as long as you give appropriate credit to the original author(s) and the source, provide a link to the Creative Commons licence, and indicate if changes were made. The images or other third party material in this article are included in the article's Creative Commons licence, unless indicated otherwise in a credit line to the material. If material is not included in the article's Creative Commons licence and your intended use is not permitted by statutory regulation or exceeds the permitted use, you will need to obtain permission directly from the copyright holder. To view a copy of this licence, visit http://creativecommons.org/licenses/by/4.0/.

\section{References}

1. Drayton DL, Liao S, Mounzer RH, Ruddle NH (2006) Lymphoid organ development: from ontogeny to neogenesis. Nat Immunol 7(4):344-353. https://doi.org/10.1038/ni1330

2. Ulrichs T, Kosmiadi GA, Trusov V et al (2004) Human tuberculous granulomas induce peripheral lymphoid follicle-like structures to orchestrate local host defence in the lung. J Pathol 204(2):217228. https://doi.org/10.1002/path.1628
3. Slight SR, Rangel-Moreno J, Gopal R et al (2013) CXCR5(+) T helper cells mediate protective immunity against tuberculosis. J Clin Invest 123(2):712-726. https://doi.org/10.1172/JCI65728

4. Sautes-Fridman C, Petitprez F, Calderaro J, Fridman WH (2019) Tertiary lymphoid structures in the era of cancer immunotherapy. Nat Rev Cancer 19(6):307-325. https://doi.org/10.1038/s41568019-0144-6

5. Corsiero E, Nerviani A, Bombardieri M, Pitzalis C (2016) Ectopic Lymphoid Structures: Powerhouse of Autoimmunity. Front Immunol 7:430. https://doi.org/10.3389/fimmu.2016.00430

6. Shipman WD, Dasoveanu DC, Lu TT (2017) Tertiary lymphoid organs in systemic autoimmune diseases: pathogenic or protective? F1000Res 6:196. https://doi.org/10.12688/f1000research.10595.1

7. Aloisi F, Pujol-Borrell R (2006) Lymphoid neogenesis in chronic inflammatory diseases. Nat Rev Immunol 6(3):205-217. https:// doi.org/10.1038/nri1786

8. Sixt M, Kanazawa N, Selg M et al (2005) The conduit system transports soluble antigens from the afferent lymph to resident dendritic cells in the $\mathrm{T}$ cell area of the lymph node. Immunity 22(1):19-29. https://doi.org/10.1016/j.immuni.2004.11.013

9. Lokmic Z, Lammermann T, Sixt M, Cardell S, Hallmann R, Sorokin L (2008) The extracellular matrix of the spleen as a potential organizer of immune cell compartments. Semin Immunol 20(1): 4-13. https://doi.org/10.1016/j.smim.2007.12.009

10. Anderson ND, Anderson AO, Wyllie RG (1976) Specialized structure and metabolic activities of high endothelial venules in rat lymphatic tissues. Immunology 31(3):455-473

11. Ruddle NH (2016) High Endothelial Venules and Lymphatic Vessels in Tertiary Lymphoid Organs: Characteristics, Functions, and Regulation. Front Immunol 7:491. https://doi.org/10.3389/ fimmu.2016.00491

12. Bajenoff M, Egen JG, Koo LY et al (2006) Stromal cell networks regulate lymphocyte entry, migration, and territoriality in lymph nodes. Immunity 25(6):989-1001. https://doi.org/10.1016/j. immuni.2006.10.011

13. Gretz JE, Norbury CC, Anderson AO, Proudfoot AE, Shaw S (2000) Lymph-borne chemokines and other low molecular weight molecules reach high endothelial venules via specialized conduits while a functional barrier limits access to the lymphocyte microenvironments in lymph node cortex. J Exp Med 192(10):1425-1440. https://doi.org/10.1084/jem.192.10.1425

14. Bajenoff M, Glaichenhaus N, Germain RN (2008) Fibroblastic reticular cells guide $\mathrm{T}$ lymphocyte entry into and migration within the splenic T cell zone. J Immunol 181(6):3947-3954. https://doi. org/10.4049/jimmunol.181.6.3947

15. Penaranda C, Tang Q, Ruddle NH, Bluestone JA (2010) Prevention of diabetes by FTY720-mediated stabilization of peri-islet tertiary lymphoid organs. Diabetes 59(6):1461-1468. https://doi.org/10. 2337/db09-1129

16. Kendall PL, Yu G, Woodward EJ, Thomas JW (2007) Tertiary lymphoid structures in the pancreas promote selection of B lymphocytes in autoimmune diabetes. J Immunol 178(9):5643-5651. https://doi.org/10.4049/jimmunol.178.9.5643

17. Link A, Hardie DL, Favre S et al (2011) Association of T-zone reticular networks and conduits with ectopic lymphoid tissues in mice and humans. Am J Pathol 178(4):1662-1675. https://doi. org/10.1016/j.ajpath.2010.12.039

18. Smeets S, Staels W, Stange G, Gillard P, De Leu N, In't Veld P (2020) Insulitis and lymphoid structures in the islets of Langerhans of a 66-year-old patient with long-standing type 1 diabetes. Virchows Arch. https://doi.org/10.1007/s00428-020-02915-4

19. Insel RA, Dunne JL, Atkinson MA et al (2015) Staging presymptomatic type 1 diabetes: a scientific statement of JDRF, the Endocrine Society, and the American Diabetes Association. Diabetes Care 38(10):1964-1974. https://doi.org/10.2337/dc15-1419 
20. Vendrame F, Pileggi A, Laughlin E et al (2010) Recurrence of type 1 diabetes after simultaneous pancreas-kidney transplantation, despite immunosuppression, is associated with autoantibodies and pathogenic autoreactive CD4 T-cells. Diabetes 59(4):947-957. https://doi.org/10.2337/db09-0498

21. Pugliese A, Reijonen HK, Nepom J, Burke GW 3rd (2011) Recurrence of autoimmunity in pancreas transplant patients: research update. Diabetes Manag (Lond) 1(2):229-238. https:// doi.org/10.2217/dmt.10.21

22. Korpos E, Kadri N, Kappelhoff R et al (2013) The peri-islet basement membrane, a barrier to infiltrating leukocytes in type 1 diabetes in mouse and human. Diabetes 62(2):531-542. https://doi.org/ $10.2337 / \mathrm{db} 12-0432$

23. Campbell-Thompson ML, Atkinson MA, Butler AE et al (2013) The diagnosis of insulitis in human type 1 diabetes. Diabetologia 56(11):2541-2543. https://doi.org/10.1007/s00125-013-3043-5

24. Arfuso F (2006) A study of physiologic angiogenesis in the human using the dental pulp as an in vivo model. Endothelium 13(5):359363. https://doi.org/10.1080/10623320600972101

25. Campbell-Thompson M, Wasserfall C, Kaddis J et al (2012) Network for Pancreatic Organ Donors with Diabetes (nPOD): developing a tissue biobank for type 1 diabetes. Diabetes Metab Res Rev 28(7):608-617. https://doi.org/10.1002/dmrr.2316

26. Morgan NG, Richardson SJ (2018) Fifty years of pancreatic islet pathology in human type 1 diabetes: insights gained and progress made. Diabetologia 61(12):2499-2506. https://doi.org/10.1007/ s00125-018-4731-y

27. Gretz JE, Kaldjian EP, Anderson AO, Shaw S (1996) Sophisticated strategies for information encounter in the lymph node: the reticular network as a conduit of soluble information and a highway for cell traffic. J Immunol 157(2):495-499

28. Kaldjian EP, Gretz JE, Anderson AO, Shi Y, Shaw S (2001) Spatial and molecular organization of lymph node $\mathrm{T}$ cell cortex: a labyrinthine cavity bounded by an epithelium-like monolayer of fibroblastic reticular cells anchored to basement membrane-like extracellular matrix. Int Immunol 13(10):1243-1253. https://doi.org/10.1093/ intimm/13.10.1243

29. Link A, Vogt TK, Favre S et al (2007) Fibroblastic reticular cells in lymph nodes regulate the homeostasis of naive $\mathrm{T}$ cells. Nat Immunol 8(11):1255-1265. https://doi.org/10.1038/ni1513
30. Tew JG, Kosco MH, Burton GF, Szakal AK (1990) Follicular dendritic cells as accessory cells. Immunol Rev 117:185-211. https://doi.org/10.1111/j.1600-065x.1990.tb00573.x

31. Heesters BA, Myers RC, Carroll MC (2014) Follicular dendritic cells: dynamic antigen libraries. Nat Rev Immunol 14(7):495504. https://doi.org/10.1038/nri3689

32. Lee Y, Chin RK, Christiansen P et al (2006) Recruitment and activation of naive $T$ cells in the islets by lymphotoxin beta receptordependent tertiary lymphoid structure. Immunity 25(3):499-509. https://doi.org/10.1016/j.immuni.2006.06.016

33. D'Alise AM, Auyeung V, Feuerer M et al (2008) The defect in Tcell regulation in NOD mice is an effect on the T-cell effectors. Proc Natl Acad Sci U S A 105(50):19857-19862. https://doi.org/10. 1073/pnas.0810713105

34. Vendrame F, Hopfner YY, Diamantopoulos S et al (2016) Risk Factors for Type 1 Diabetes Recurrence in Immunosuppressed Recipients of Simultaneous Pancreas-Kidney Transplants. Am J Transplant 16(1):235-245. https://doi.org/10.1111/ajt.13426

35. In't Veld P (2014) Insulitis in human type 1 diabetes: a comparison between patients and animal models. Semin Immunopathol 36(5): 569-579. https://doi.org/10.1007/s00281-014-0438-4

36. Campbell-Thompson M, Fu A, Kaddis JS et al (2016) Insulitis and beta-Cell Mass in the Natural History of Type 1 Diabetes. Diabetes 65(3):719-731. https://doi.org/10.2337/db15-0779

37. MacLennan IC (1994) Germinal centers. Annu Rev Immunol 12: 117-139. https://doi.org/10.1146/annurev.iy.12.040194.001001

38. Leete P, Willcox A, Krogvold L et al (2016) Differential Insulitic Profiles Determine the Extent of beta-Cell Destruction and the Age at Onset of Type 1 Diabetes. Diabetes 65(5):1362-1369. https://doi. org/10.2337/db15-1615

39. Craig ME, Kim KW, Isaacs SR et al (2019) Early-life factors contributing to type 1 diabetes. Diabetologia 62(10):1823-1834. https://doi.org/10.1007/s00125-019-4942-x

40. Martin-Pagola A, Sisino G, Allende G et al (2008) Insulin protein and proliferation in ductal cells in the transplanted pancreas of patients with type 1 diabetes and recurrence of autoimmunity. Diabetologia 51(10):1803-1813. https://doi.org/10.1007/s00125008-1105-x

Publisher's note Springer Nature remains neutral with regard to jurisdictional claims in published maps and institutional affiliations. 